\title{
Temperature Monitoring in Hyperthermia Treatments of Bone Tumors: State-of-the-Art and Future Challenges
}

\author{
Francesca De Tommasi ${ }^{1}$ (D), Carlo Massaroni ${ }^{1}$ D, Rosario Francesco Grasso ${ }^{2}$, Massimiliano Carassiti ${ }^{3}$ and \\ Emiliano Schena $1, *$ (i)
}

1 Unit of Measurements and Biomedical Instrumentations, Department of Engineering, Università Campus Bio-Medico di Roma, Via Alvaro del Portillo, 00128 Rome, Italy; f.detommasi@unicampus.it (F.D.T.); c.massaroni@unicampus.it (C.M.)

2 Unit of Interventional Radiology, School of Medicine, Università Campus Bio-Medico di Roma, Via Alvaro del Portillo, 00128 Rome, Italy; r.grasso@unicampus.it

3 Unit of Anesthesia, Intensive Care and Pain Management, School of Medicine, Università Campus Bio-Medico di Roma, Via Alvaro del Portillo, 00128 Rome, Italy; m.carassiti@unicampus.it

* Correspondence: e.schena@unicampus.it

check for updates

Citation: De Tommasi, F.; Massaroni, C.; Grasso, R.F.; Carassiti, M.; Schena, E. Temperature Monitoring in Hyperthermia Treatments of Bone Tumors: State-of-the-Art and Future Challenges. Sensors 2021, 21, 5470. https: / / doi.org/10.3390/s21165470

Academic Editor: Cristian Pantea

Received: 23 July 2021

Accepted: 10 August 2021

Published: 13 August 2021

Publisher's Note: MDPI stays neutral with regard to jurisdictional claims in published maps and institutional affiliations.

Copyright: (c) 2021 by the authors. Licensee MDPI, Basel, Switzerland. This article is an open access article distributed under the terms and conditions of the Creative Commons Attribution (CC BY) license (https:/ / creativecommons.org/licenses/by/ $4.0 /)$.

\begin{abstract}
Bone metastases and osteoid osteoma $(\mathrm{OO})$ have a high incidence in patients facing primary lesions in many organs. Radiotherapy has long been the standard choice for these patients, performed as stand-alone or in conjunction with surgery. However, the needs of these patients have never been fully met, especially in the ones with low life expectancy, where treatments devoted to pain reduction are pivotal. New techniques as hyperthermia treatments (HTs) are emerging to reduce the associated pain of bone metastases and OO. Temperature monitoring during HTs may significantly improve the clinical outcomes since the amount of thermal injury depends on the tissue temperature and the exposure time. This is particularly relevant in bone tumors due to the adjacent vulnerable structures (e.g., spinal cord and nerve roots). In this Review, we focus on the potential of temperature monitoring on HT of bone cancer. Preclinical and clinical studies have been proposed and are underway to investigate the use of different thermometric techniques in this scenario. We review these studies, the principle of work of the thermometric techniques used in HTs, their strengths, weaknesses, and pitfalls, as well as the strategies and the potential of improving the HTs outcomes.
\end{abstract}

Keywords: bone tumors; CT thermometry; fiber Bragg grating sensors; fluoroptic sensors; hyperthermia treatments; MR thermometry; thermocouples; thermistors; temperature monitoring; ultrasound thermometry

\section{Introduction}

Cancer is one of the leading causes of mortality worldwide, with an ever-growing number of people affected. By 2025, it is estimated over 20 million people will suffer from this disease each year [1]. In this context, patients facing primary lesions in the breast, lung, and prostate have a propensity to inherit bone metastases during their illness, with an estimated incidence of more than 60\% [2-6]. In addition to metastatic lesions, osteoid osteoma (hereafter $\mathrm{OO}$ ) is a quite frequent benign tumor involving bone with small dimensions (up to $1.5 \mathrm{~cm}$ in diameter), affecting mainly young patients $[7,8]$. Whereas bone metastases primarily have spine involvement $[9,10], \mathrm{OO}$ is predominantly in anatomical sites such as the femur and tibia [8,11]. Patients affected by bone lesions (both primary and metastatic ones) suffer from acute pain intensifying during the night, thus resulting in a poor-quality life [12,13]. In this scenario, pain reduction in a lasting way is a priority, especially in patients with low life expectancy [14]. To date, a standard treatment for managing such kinds of lesions is radiotherapy, as stand-alone dealing or in conjunction with surgery, which remains the gold standard, especially in patients with bone fractures involvement [15-17]. Nevertheless, both these approaches exhibit some limitations: radiotherapy may need some weeks before providing possible benefits, low radiation tolerance 
for tumors in the proximity of vulnerable structures, and inability to treat patients with previous comorbidities [14,18].

For almost thirty years, hyperthermia treatments (hereafter HTs) have been gaining momentum in this arena. Such procedures have emerged as valuable alternatives to traditional therapies in bone cancer, owing to their minimally invasive nature [19-22]. Given the success rate in tumor control and the immediate effect of pain relief, HTs have been identified as a possible treatment in bone metastases by the National Comprehensive Cancer Network in its November 2020 guidelines [23]. The main principle of HTs is to achieve complete and effective cancer removal by raising cytotoxic temperatures (i.e., $>50{ }^{\circ} \mathrm{C}$ ) [24]. Among HTs, radiofrequency ablation (RFA), laser ablation (LA), and microwave ablation (MWA) are well documented in the literature for bone malignancy management [11,25-29]. Such procedures are performed via percutaneous access whereby a needlelike applicator is positioned within the tumor tissue under imaging guidance (e.g., computed tomography -CT-, magnetic resonance -MR-) [30,31]. RFA, LA, and MWA working principles differ according to the energy source employed, and cell necrosis is achieved by a localized increase in temperature because of energy-tissue interaction [24]. Differently from RFA, LA and MWA, high intensity focused ultrasound (hereafter HIFU) represents another technique belonging to the hyperthermia-based procedures totally non-invasive since it does not require the insertion of a needlelike applicator inside the treated area. In HIFU, the temperature rising is accomplished by means of a mechanical transducer placed on the external body surface corresponding to the area to be treated [32]. In the last decades, HIFU has been broadly exploited to treat bone tumors owing to the promising results reported, especially in terms of pain relief [33-36].

During HTs, the amount of thermal injury is strongly related to the temperature experienced by the tissue during the procedure and the exposure time, as outlined by the most popular models (e.g., Arrhenius' law, CEM $43{ }^{\circ} \mathrm{C}$ [37]). Temperature monitoring in HTs is paramount to ensure damage to the tumor portion plus a reasonable safety margin while preserving healthy surrounding anatomical structures [38,39]. Therefore, keeping track of temperature changes over time accounts for valuable information to the clinician performing the procedure. Real-time temperature understanding allows adjusting treatment settings (e.g., input power and treatment time) to clearly identify the endpoint and ensure the safety of the procedure [40-42]. To date, commercially available hyperthermia systems are equipped with temperature sensors embedded within the energy source. However, this solution does not provide information about heat propagation inside the tissue undergoing ablation while exclusively intended to ensure temperatures at the source tip not exceeding a safety value generally set on the HT systems. Otherwise, temperature tissue monitoring may be accomplished by many either contact or contactless techniques with different purposes. Among others, temperature map reconstruction resulting from tissue temperature measurements allows accurately estimating tissue damage, thus achieving a good match between the portion of tissue that should be damaged and the one that experiences cytotoxic temperatures during the procedure. Temperature knowledge gains further relevance in bone tumors growing adjacent to vulnerable structures such as the spinal cord and nerve roots [43]. The dealing of such lesions is characterized by the major challenge of preventing cytotoxic temperatures in susceptible areas [44]. Indeed, neural elements are not allowed experiencing temperatures higher than $45^{\circ} \mathrm{C}$ since this would lead to permanent damage including in the worst cases paralysis or paresis that severely impact the patients' status [22,45-47]. Therefore, both thermal insulation techniques and temperature monitoring are mandatory in this scenario to improve the procedure's safety and efficacy $[46,48,49]$. While the firsts are carried out by injecting $\mathrm{CO}_{2}$ or saline solution to create thermal dissection, temperature monitoring leads the way to correctly gather temperature information in the treated tissue without compromising sensitive elements [46,50,51]. Moreover, temperature measurement plays a key role in investigating the effectiveness of either available or novel ablation devices, thus affording optimization and understanding their performances, as well as gaining new findings on how various HT settings affect the 
treatment effects. In addition, single-point temperature measurements are broadly accepted in clinical settings to protect vulnerable anatomical areas from cytotoxic temperatures. In these cases, thermometers must be carefully inserted in the proximity of these structures by avoiding undesirable injuries.

In spite of this potential impact, temperature monitoring is not well established in clinical settings since it presents several open challenges when performed during HTs.

In this paper, we will provide an overview of the principal thermometric techniques used in the field of HTs, focusing on the specific application in bone cancer. The widespread solutions will be presented by briefly describing their working principle and the principal strengths and weaknesses of using such technologies in this scenario. Next, we will describe state-of-the-art related to these thermometric techniques in each bone HT (i.e., RFA, LA, MWA, and HIFU). Finally, we will emphasize our personal point of view concerning the current status with the aim to provide valuable insights, current and future challenges on this topic.

\section{Temperature Monitoring: Main Techniques and Applications in Bone HTs}

Extensive investigations have been devoted to providing suitable solutions for continuous temperature monitoring during HT since the knowledge of temperature may be beneficial to ensure the procedure's safety.

This section is devoted to describing the most popular techniques used for temperature monitoring in HTs of bone cancer in preclinical and clinical studies.

Firstly, the principle of work of the most popular thermometric techniques is described, along with the main strengths, weaknesses, and pitfalls. Then, applications of the mentioned techniques in HTs of bones will be described: Section 2.2 will be devoted to in-bone temperature monitoring during RFA, Section 2.3 during LA, Section 2.4 during MWA, and Section 2.5 during HIFU.

\subsection{Most Popular Thermometric Techniques Used during HTs}

Basically, thermometric techniques employed in this scenario can be classified as either contact-based or contactless methods (see Figure 1) [39]. Contact-based techniques involve the insertion of the sensing element within the treated tissue. This category includes thermocouples, thermistors, fluoroptic, and fiber Bragg grating (FBG) sensors. Contactless techniques do not require direct contact with the measurement site. This category involves diagnostic imaging techniques (i.e., magnetic resonance imaging, MRI, computed tomography, CT, and ultrasound thermometry) [39].

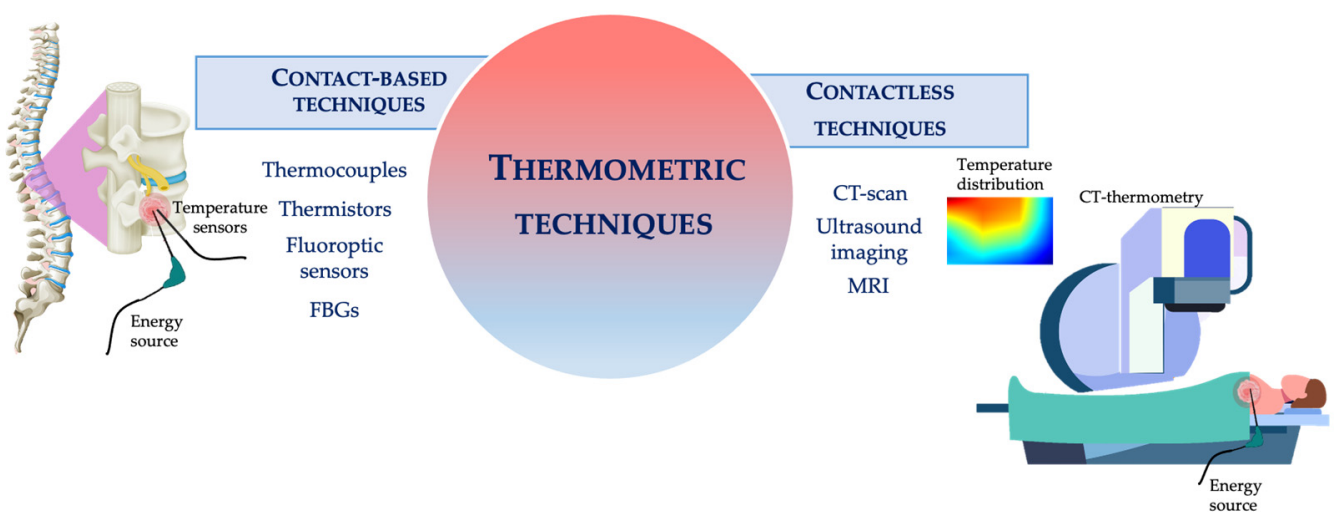

Figure 1. Schematic representation of the thermometric techniques employed during HTs.

\subsubsection{Contact Based Techniques}

A thermocouple consists of two different metal wires (conductors A and B) joined together in correspondence of the so-called hot junction. This is the junction where the temperature to be measured is applied. The other extremity (i.e., the cold junction) consists 
of two free conductors at known temperature. Thermocouple's working principle is based on Seeback effect. When a temperature gradient between the two junctions occurs, an electromotive force (emf) can be measured, as evidenced by the equation [52]:

$$
\mathrm{emf}=\int_{\mathrm{T}_{\mathrm{ref}}}^{\mathrm{T}_{1}} \mathrm{~S}_{\mathrm{A}}(\mathrm{T}) \mathrm{dT}-\int_{\mathrm{T}_{\mathrm{ref}}}^{\mathrm{T}_{1}} \mathrm{~S}_{\mathrm{B}} \mathrm{dT}=\int_{\mathrm{T}_{\mathrm{ref}}}^{\mathrm{T}_{1}} \mathrm{~S}_{\mathrm{AB}}(\mathrm{T}) \mathrm{dT}
$$

where $T_{\text {ref }}$ and $T_{1}$ represent the cold junction temperature and the temperature to be measured, respectively. $S_{A}, S_{B}$, and $S_{A B}$ denote the Seeback coefficients for conductor $A, B$ and joined conductors (i.e., thermocouple), respectively. According to the applications, it is possible to choose a specific type of thermocouple by means of a different conductors combination (e.g., chromel/alumel, copper/constantan, iron/constantan). Each combination is characterized by different performances in terms of sensitivity, accuracy, and measurement range. Thermocouples found application in HTs for the first time in 1935 [53]. After this early investigation, several studies have evidenced their use during HTs [54-60]. The widespread acceptance of thermocouples is attributable primarily to their low cost, small size, robustness, wide measuring range and fast response time [61]. Nevertheless, the main drawback is related to the metallic composition not allowing their use in the presence of high electromagnetic fields (e.g., during MR scans). In case of LA, the metallic components may cause a measurement artifact due to the absorption of light $[62,63]$.

Thermistors are composed of semiconductors materials that change their resistance in response to temperature variations. The relationship resistance-temperature is described by a non-linear law, as expressed by the following equation:

$$
\mathrm{R}=\mathrm{R}_{0} \mathrm{e}^{\beta\left(\frac{1}{\mathrm{~T}}-\frac{1}{\mathrm{~T}_{0}}\right)}
$$

where $R_{0}$ and $T_{0}$ represent the initial resistance and temperature conditions, $\beta$ is a constant characteristic of the semiconductor employed, and $\mathrm{R}$ is the resistance measured at temperature T. These transducers can be classified in two different categories: (i) thermistors with a Positive Temperature Coefficient (PTC), which exhibit a resistance increment because of an increase in temperature; (ii) thermistors characterized by a Negative Temperature Coefficient (NTC) responding by decreasing resistance when a temperature increase occurs [64]. Among these two categories, NTC thermistors are the most popular ones. In the field of HTs, the first application of thermistor dates back in 1976 [65] when researchers developed a thermal probe embedding one thermistor to evaluate the effect of RF fields in biological tissue. Due to their cost-effectiveness, small size, robustness, high sensitivity, fast response time, and good accuracy, further studies have adopted these thermometers to measure temperature in HTs [66-71]. It is worth pointing out that both thermocouples and thermistors can provide a temperature measured in a single point of the tissue. Therefore, their use allows gathering temperature information in a specific anatomical point [39].

Fluoroptic and FBGs sensors belong to the large optical sensors' category. In the last decades, optical sensing technologies have gained momentum in various biomedical applications due to their remarkable metrological properties [72-77]. Specifically, the fluoroptic sensor consists of a fluorescent material bonded to a fiber optic tip, representing the fiber's sensing portion. Their principle of work relies on the decay time of the fluorescent material (e.g., ruby, alexandrite, thulium, rare-earth phosphors) [74,75]. When a light pulse travels inside the fiber, such material is excited. The fluorescent signal resulting from the excitation travels back in the fiber. After the excitation, the signal decays with an exponential low depending on the fluorescent material's temperature, as reported in the following equation [78]:

$$
\mathrm{I}_{\mathrm{P}}=\mathrm{I}_{0} \mathrm{e}^{\frac{-\mathrm{t}}{\tau}}
$$

where $I_{0}$ is the initial intensity value, $t$ is the time, $\tau$ the time constant, and $I_{p}$ the emitted signal intensity. From this equation, it is possible to estimate temperature since its dependency on $\tau$. In ablation treatments, the first exploits of fluoroptic sensors appeared in the 
90s and viewed as the main application the treatment of cardiac arrhythmias [79-81]. After these early investigations, substantial studies reported the use of fluoroptic sensors in liver, prostate, and breast cancer [82-85]. The popularity of fluoroptic sensors is mainly due to their non-toxicity, biocompatibility, small size, immunity to electromagnetic fields, wide measuring range (generally $25^{\circ} \mathrm{C}-300{ }^{\circ} \mathrm{C}$ ), and high accuracy (around $0.2{ }^{\circ} \mathrm{C}$ ) [74,78]. Nevertheless, it should be kept in mind that fluorescence thermometry may cause measurement errors due to the sensor overheating during the HT [39].

FBGs were introduced for the first time in 1978 [86]. Basically, an FBG is an intrinsic optical sensor inscribed inside the core of an optical fiber consisting of a fiber's portion in which a periodic modulation of the refractive index occurs. The incidence of a broadband light source on the grating results in a reflection of a narrow spectrum centered around a specific wavelength (i.e., the Bragg wavelength $\lambda_{\mathrm{B}}$ ) satisfying the Bragg condition expressed in the following equation [87]:

$$
\lambda_{\mathrm{B}}=2 \cdot \mathrm{n}_{\mathrm{eff}} \cdot \Lambda
$$

As highlighted by Equation (4), $\lambda_{B}$ value is determined by the effective refractive index (i.e., $\left.\mathrm{n}_{\text {eff }}\right)$ and the grating period (i.e., $\left.\Lambda\right)$. $\lambda_{B}$ shift $\left(\Delta \lambda_{B}\right)$ occurs when the fiber is exposed to strain or temperature variations. Thus, by measuring $\Delta \lambda_{\mathrm{B}}$ it is possible to retrieve the strain, or temperature variations. In HTs, FBGs are used as temperature sensors only by implementing strain free-configurations or adequate filtering stages, especially for vivo trials where breathing-related organ movements can potentially cause measurement artifacts [88,89]. FBGs have found applications in RFA [90-93], LA [94-97], MWA [98-101] and HIFU [102]. The overgrowing number of studies employing FBGs to perform temperature measurements is explained by several advantages making them more powerful than other thermometric techniques. In addition to the features already listed for fluoroptic sensors, FBGs are recognized for their multiplexing capability, allowing multiple sensors within a single fiber [103]. Thus, knowledge about heat distribution in the surrounding tissues can be easily gathered. Anyway, the interrogation system required to both power the fiber and retrieve data makes optical sensors very expensive.

\subsubsection{Contactless Techniques}

This category involves diagnostic imaging techniques (i.e., MRI, CT and ultrasound thermometry), allowing a temperature mapping reconstruction during the procedure [39]. CT scan is a popular diagnostic imaging method employed in clinical practice to examine body sections for the diagnosis of several diseases. The digital imaging resulting from a CT scan is constructed from pixels representing the linear attenuation coefficients of the examined tissues, which are processed and converted into CT numbers (expressed in Hounsfield Unit, HU) obtaining from the following equation [104]:

$$
\mathrm{CT}(\mathrm{x}, \mathrm{y})=\frac{1000 \cdot\left[\left(\mu(\mathrm{x}, \mathrm{y})-\mu_{\mathrm{W}}\right)\right]}{\mu_{\mathrm{W}}}
$$

where $\mu_{\mathrm{W}}$ is the water linear attenuation coefficient and $\mu(\mathrm{x}, \mathrm{y})$ is the average linear attenuation coefficient in the $(x, y)$ voxel. The linear attenuation coefficient depends on tissue- $X$ ray interaction, resulting from Compton effect. This phenomenon is mainly affected by tissue density $(\rho)$ which inversely depends on temperature variation as evidenced by the following equation [105]:

$$
\rho(\mathrm{T})=\frac{\rho\left(\mathrm{T}_{0}\right)}{1+\alpha \cdot \Delta \mathrm{T}}
$$

where $\Delta \mathrm{T}$ is the temperature variation, $\mathrm{T}_{0}$ is the room temperature and $\alpha$ is the thermal expansion coefficient. Using a Taylor series linearization, it is possible to estimate temperature by CT numbers. CT thermometry appeared in HTs in the early of 1980s [106-108]. Since its first application, studies employing this technology are not lacking [55,109-116]. CT thermometry exhibits good spatial resolution, a fast acquisition time if compared to 
other diagnostic techniques (e.g., MR) and a temperature precision around $3{ }^{\circ} \mathrm{C}$. Whereas, one concern is the radiation dose [117].

During ultrasound imaging, a high-frequency sound wave is transmitted within the human body by means of a mechanical transducer. The resulting ultrasound image is made up of the echoes generated by the reflection of ultrasound waves. The depth of the examined tissue can be estimated according to the time elapsed between the wave sending and the detection of the reflected wave by the transducer. The time delay can be measured using the below equation [118]:

$$
\mathrm{t}\left(\mathrm{T}_{0}\right)=\frac{2 \mathrm{z}}{\mathrm{v}_{\mathrm{s}}\left(\mathrm{T}_{0}\right)}
$$

in which $t\left(T_{0}\right)$ represents the time delay of the reflected wave measured at the depth $\mathrm{z}$ and temperature $T_{0}$. When a temperature variation $(\Delta T)$ occurs because of the medium's thermal expansion and changes in the sound speed, a time shift $(\Delta t)$ can be measured. The relationship between $\Delta \mathrm{T}$ and $\Delta \mathrm{t}$ can be expressed by the Equation (7), considering negligible the contribution due to the thermal expansion compared to sound speed [119].

$$
\Delta \mathrm{T}=\mathrm{k}_{1} \frac{\mathrm{d}(\Delta \mathrm{t})}{\mathrm{dt}}
$$

In Equation (8), $\mathrm{k}_{1}$ is a tissue constant and the term $\frac{\mathrm{d}(\Delta \mathrm{t})}{\mathrm{dt}}$ the normalized time shift. Thus, temperature distribution inside the tissue can be obtained by considering the dependence of $\mathrm{T}$ on the sound speed. Ultrasound-based thermometry emerged in 1979 [120] and then found broad acceptance in all HTs [121-124] except for HIFU ablation, where the employment of this method should be avoided to prevent cross-talking phenomena [125]. In addition to its non-invasiveness, this technique does not require ionizing radiation and is quite inexpensive as compared to other imaging techniques. However, this thermometry may be affected by measurement artifact due to the patient's breathing and motions [39].

MR provides diagnostic images by applying an external magnetic field. Hydrogen protons are mainly responsible for the diagnostic image resulting from an MR scan. These protons and their electric charge revolve around an axis (usually said to have spin). When a high external magnetic is applied $\left(\mathrm{B}_{0}\right)$, the proton axis will be oriented along the field itself. The orientation can occur in the same direction of $\mathrm{B}_{0}$ (i.e., configuration with low energy) or in the opposite one (i.e., configuration with high energy level). In addition, in presence of $B_{0}$, the axis of each proton revolves with respect to $B_{0}$, at a defined frequency, called precession frequency. To resonate the hydrogen proton, a radiofrequency signal with frequency equal to the precession one is applied. After its interruption, the proton spins return to their initial condition. This phenomenon can be described by two time-related parameters (i.e., spin-lattice relaxation time, T1 and longitudinal relaxation time, T2) [126]. Several MR parameters exhibiting temperature dependence have been investigated [127]. Among others, $\mathrm{T} 1$ and proton resonance frequency (hereafter PRF) were found to be most promising [128]. The relationship between $\mathrm{T} 1$ and temperature is expressed by the following equation [129]:

$$
\mathrm{T} 1 \propto \exp \left(-\frac{\mathrm{E}_{\mathrm{a}}(\mathrm{T} 1)}{\mathrm{k} \cdot \mathrm{T}}\right)
$$

where $E_{a}(T 1)$ denotes the activation energy of the relaxation process, $k$ the Boltzmann constant and $\mathrm{T}$ is the absolute temperature. The relationship described can be considered almost linear for temperature ranging between $30^{\circ} \mathrm{C}$ and $70{ }^{\circ} \mathrm{C}$ [39]. The main drawback related to the use of this technique is the $\mathrm{T} 1$ dependence on the tissue that may affect the measurement. Another parameter used to measure temperature is the PRF. This technique overcomes limitations due to the tissue type dependence and shows high precision in measuring temperature variations. In this case, $\Delta \mathrm{T}$ is related to the image phase according to the below equation [130]:

$$
\Delta \mathrm{T}=\frac{\varphi(\mathrm{T})-\varphi(\mathrm{T} 0)}{\gamma \cdot \alpha_{1} \cdot \mathrm{B}_{0} \cdot \mathrm{TE}}
$$


where $\alpha_{1}$ is the PRF variation coefficient, TE is the echo time, $\gamma$ is the hydrogen gyromagnetic ratio, $\varphi(\mathrm{T})$ and $\varphi\left(\mathrm{T}_{0}\right)$ the image phases at temperature $\mathrm{T}$ and $\mathrm{T}_{0}$, respectively. In 1988, MR thermometry found application for the first time in LA [131]. Subsequently, substantial research about MR-guided temperature monitoring during HTs was carried out $[83,132-139]$.

\subsection{Temperature Monitoring during RFA in Bone}

After a short description of the RFA principle of work, we explore the main studies focused on temperature monitoring during RFA.

RFA differs according to the working modality (i.e., monopolar, or bipolar). In monopolar mode, a high-frequency alternating current (typically between $350 \mathrm{kHz}$ and $500 \mathrm{kHz}$ ) [38] is delivered into the tumor tissue by means of an electrode with an exposed tip (i.e., the active electrode). A RF generator produces a voltage difference between the active electrode and a ground pad placed on the patient's skin. The applied current causes ionic agitation in the tissue around the exposed tip; as a result, tissue heating due to the Joule effect occurs [24]. In bipolar mode, the current flow is established between two electrodes both in contact with the tissue, and no ground pad is required [140].

The first application of bone RFA in a clinical trial dates back to 1992, as reported in a scientific article published by Rosenthal et al. [141]. This study reported four case studies of patients affected by OO in different anatomical sites and treated with RFA. After these early investigations, RFA has won extensive clinical acceptance in the treatment of bone tumors [26,142-147].

Among a huge number of studies focused on bone RFA, many of them have also investigated temperature monitoring.

In [43], Dupuy et al. carried out RFA on both in vivo pigs and ex vivo samples by performing simultaneous temperature assessment during treatment. Five pigs underwent RFA after being anesthetized. The procedure was performed in lumbar vertebral bodies (L1-L3) and paraspinal muscles (total of 10 procedures, 5 for each anatomical site). Three holes were drilled into the vertebral body using a biopsy needle to position RF probe and three thermistors. The treatment was carried out for an application time of $12 \mathrm{~min}$ at the maximum current and $1 \mathrm{~cm}$ of the active tip. The three thermistors were positioned adjacent to the spinal canal at $5 \mathrm{~mm}, 10 \mathrm{~mm}$, and $15 \mathrm{~mm}$ from the probe. Temperature values were recorded each 5 min during and after the RFA until the temperature return to the initial value. During ex vivo experiments, samples of cancellous and cortical bone were subjected to RFA for $6 \mathrm{~min}$ using an RF probe with $2 \mathrm{~cm}$ of the active tip. In these experiments two thermistors were positioned at $10 \mathrm{~mm}$ away from the tip, in both bone sides in case of cortical bone. Results showed differences in temperature values recorded inside the vertebral body compared to those in the paraspinal muscle in correspondence of $10 \mathrm{~min}$ (i.e., lower values in the first case than in the second at the same distances). In the epidural space temperature was equal to $44^{\circ} \mathrm{C}$. Temperatures assessed in ex vivo evidenced an insulating effect of cortical bone. Indeed, at the same distance of $10 \mathrm{~mm}$ but on opposite sides of bone samples, thermistor in the proximity of bone cortex registered higher value than the one positioned in the cortical bone (i.e., $25.7 \pm 7.0^{\circ} \mathrm{C}$ and $11.2 \pm 2.0^{\circ} \mathrm{C}$, respectively).

In [148], the RFA feasibility in bone was assessed by estimating the heat distribution both in cortical bone and marrow in ten ex vivo bovine tibia. Five holes of $2 \mathrm{~mm}$ in diameter were drilled in the tissue to allow thermocouples insertion parallel to the RF electrode. The holes were cut at several depths and a distance of $5 \mathrm{~mm}$ radially. Twelve measurements were performed for each distance, and temperature values were recorded every $1 \mathrm{~s}$. RFA was served with a cool-tip probe for a maximum application time of $30 \mathrm{~min}$. In the bone marrow, mean temperature values of more than $50{ }^{\circ} \mathrm{C}$ were found at distances of $5 \mathrm{~mm}$, $10 \mathrm{~mm}$, and $15 \mathrm{~mm}$. In correspondence of $20 \mathrm{~mm}$, an exposure time of $30 \mathrm{~min}$ was not sufficient to reach $50^{\circ} \mathrm{C}$. In cortical bone, temperatures were lower than those experienced by bone marrow at the same positions (i.e., probe tip, $5 \mathrm{~mm}$ and $10 \mathrm{~mm}$ ). 
Temperature changes in tissue surrounding bone during RFA of OO were also investigated in [149]. Experiments were conducted in ex vivo animal model (i.e., excised bovine tibia). The OO nidus (i.e., the core of tumor mass) was mimicked by a hole filled with agarose. Based on the thickness of cortical bone between the periosteum and the nidus (i.e., $1 \mathrm{~mm}, 3 \mathrm{~mm}$, and $5 \mathrm{~mm}$ ), the authors distinguished three groups, each accounted for three specimens. Three thermocouples were inserted into each sample at the following positions: (i) in direct contact with the periosteum, (ii) at $5 \mathrm{~mm}$, and (iii) $10 \mathrm{~mm}$ from the periosteum. The RFA was performed by setting a target temperature to $95^{\circ} \mathrm{C}$ and a treatment time of $400 \mathrm{~s}$, and temperatures were recorded at regular intervals of $10 \mathrm{~s}$ during the procedure. Results revealed an influence of cortical bone thickness on heat propagation. Indeed, the highest temperature values (up to $69.3^{\circ} \mathrm{C}$ ) were recorded in the case of $1 \mathrm{~mm}$-cortical thickness in all three measurement sites when compared with the other two groups $\left(59.2^{\circ} \mathrm{C}\right.$ for $3 \mathrm{~mm}$ thickness and $50.6{ }^{\circ} \mathrm{C}$ for $5 \mathrm{~mm}$ thickness). This study highlights how a specific anatomical parameter may impact on temperature distribution, thus on the irreversible thermal injury in the surrounding structures.

In [150], the safety of RFA was evaluated by measuring the temperature inside lumbar vertebral bodies both in the presence and in the absence of a cortical bone defect. The evaluation was performed on both in vivo and ex vivo experiments. In the first case, ten lumbar vertebral bodies of six porcine adults were subjected to RFA with an active tip of either $1 \mathrm{~cm}$ or $2 \mathrm{~cm}$. Three k-type thermocouples were used to monitor the temperature every $30 \mathrm{~s}$ in the intervertebral foramen, within the vertebral body, and at the frontal vertebral surface. Differently, two thermocouples were employed in ex vivo experiments. In this case, the authors evaluated heat distribution in six lumbar vertebral bodies excised with and without cortical bone. Thermocouples were allocated so temperature could be measured within the spinal canal and in the paravertebral area at regular intervals of $30 \mathrm{~s}$. The in vivo study allowed comparing temperatures in the spinal canal in case of $1 \mathrm{~cm}$ active tip electrode with those recorded during RFA carried out with a $2 \mathrm{~cm}$ active tip probe. Differently, ex vivo experiments were carried out to compare temperature values during RFA in tissue samples with and without cortical defect. Specifically, during in vivo tests, the temperature recorded was much higher in the RF probe with $2 \mathrm{~cm}$ of the active tip, especially for the spinal canal and vertebral body. Ex vivo experiments pointed to higher temperatures in cortical bone defect samples, most notably in the spinal canal. The authors proved the risk for irreversible thermal damage occurring in nerve structures in both case studies.

In [151], authors aimed at evaluating the usefulness of real-time temperature monitoring within the spinal canal for bone tumors contiguous to the marrow. The study included ten patients with spinal metastases (i.e., 3 in thoracic spine, 6 in the lumbar, and 1 in the sacral area) resulting from previous primary tumors. All tumors were in proximity of the spinal cord (mean distance of $2.4 \pm 1.6 \mathrm{~mm}$ ). A thermocouple positioned between the tumor mass and the spinal cord (precisely in the epidural space in six cases and in the subarachnoid space in four others) allowed monitoring temperature in real-time at its tip since it was connected to an external monitor. In all procedures but one, the temperature did not exceed $45^{\circ} \mathrm{C}$. In a single case, thermocouple recorded $48^{\circ} \mathrm{C}$ causing a temporary neural injury for the patient fixed by steroid injection. The study evidenced the importance of temperature monitoring as a key method to prevent acute complications in lesions involving the spinal cord.

In [152], temperature was monitored inside the human cadaver vertebrae by three k-type thermocouples. The aim was to compare three different ablation devices (two different RF probes, $20 \mathrm{~mm}$ array, and $10 \mathrm{~mm}$ single electrode, and one coablation device). The thermocouples were positioned under fluoroscopic guidance in the vertebral body, epidural space, and neural foramen. Temperatures recorded at the end of the treatment revealed the safety of coablation to treat metastatic lesions located in vertebral body. 
In [153], temperature was measured by a thermocouple positioned parallel to a bipolar RF probe in an ex vivo vertebral body. The thermocouple allowed verifying that temperature outside the target tissue was keeping around the physiological value.

In [154], RFA was carried out on long bovine bone cut into $5 \mathrm{~cm}$ and $10 \mathrm{~cm}$ pieces within which holes were drilled into the cortical and cancellous bone to simulate OO's cavity. The created cavity was filled with homogenized liver and agar to mimic the nidus of the tumor mass. Temperatures were measured at a sampling frequency of $1 \mathrm{~Hz}$ using thermocouple embedded within a multiple RF probe at different distances (from $2 \mathrm{~mm}$ to $14 \mathrm{~mm}$ ) from the tumor edge. For tumors less than $10 \mathrm{~mm}$ in diameter, temperatures recorded in cancellous bone were higher than those in cortical bone for the same size tumor and distance. Through a multiple regression analysis, a predictive model to estimate temperatures in cortical and cancellous bone was defined as follow:

$$
\begin{aligned}
& \mathrm{T}=43.051+1.965 \times \mathrm{D}-17.335 \times \log (\mathrm{DFE}) \\
& \mathrm{T}=72.249+2.66 \times \mathrm{D}-47.246 \times \log (\mathrm{DFE})
\end{aligned}
$$

where $\mathrm{T}$ is predicted temperature in cortical (for the first equation) and cancellous bone (for the second equation), D is the tumor diameter in $\mathrm{mm}$, and DFE is the distance between the tumor edge and the temperature measurement site. This study paves the way for a clinical tool which may enable treatment planning for patients with OO.

In [45], temperature distribution during RFA in ex vivo vertebral bodies was evaluated to test a new spinal ablation device. Sixteen vertebrae (i.e., 8 lumbar and 8 thoracic vertebrae) collected from human cadavers were subjected to RFA. In this study, temperature measurements were accomplished by means of three k-type thermocouples placed inside the vertebral body, in the neuroforamen, and the spinal canal and recorded every $30 \mathrm{~s}$. The results showed no significant differences in terms of temperature recorded in lumbar versus thoracic vertebrae. A similar study was reported by the same research group [155], aiming at comparing three different kinds of RF probe.

In [156], ex vivo and in vivo experiments allowed evaluating the effect of heat distribution in the spinal canal and in the surrounding areas of vertebral bodies during RFA. RF probe consisted of a needle equipped with 13 hooked electrodes (see Table 1). The first studies were performed in vitro by means of thirty ex vivo swine vertebral bodies divided in two groups: (i) a first group in which RFA was accomplished inserting the electrode tip at a depth of $10 \mathrm{~mm}$ and (ii) a second group where the tip was introduced for $20 \mathrm{~mm}$. Before and after the procedure, temperature changes were recorded at $10 \mathrm{~mm}$ and $20 \mathrm{~mm}$ from the RF probe and in the front wall of the spinal canal and the ventral side of the vertebra. Differently, for in vivo assessment, two pigs were subjected to RFA in the lumbar vertebral body. Under imaging guidance, thermistors were placed in three different vertebral body sites: (i) at a depth of $10 \mathrm{~mm}$; (ii) posterior area; and (iii) lateral area. Temperature values were recorded every $5 \mathrm{~min}$ and up to $20 \mathrm{~min}$ during the procedure. Results obtained for in vitro trial revealed temperatures higher in Group 2 than Group 1, with a value up to $50.8^{\circ} \mathrm{C}$ in the spinal canal at the end of the ablation. Moreover, temperature recorded at $20 \mathrm{~mm}$ from the probe was higher than the ones showed for $10 \mathrm{~mm}$ (i.e., $37.7 \pm 2.0^{\circ} \mathrm{C}$ and $33.7 \pm 1.7^{\circ} \mathrm{C}$, respectively). In vivo experiments showed temperature values always lower than $45^{\circ} \mathrm{C}$ (i.e., cytotoxic threshold) in the posterior and the lateral areas, thus avoiding spinal cord impairment.

In [51], a thermocouple was inserted into the epidural space to monitor temperature variations in the anatomic area lying between the posterior site of the vertebral body and the dura mater. RFAs were performed in thirteen patients affected by lumbar tumors. During the treatment, temperature monitoring was carried out in combination with hydrodissection (in 11 cases). The temperature provided by the thermocouple was used to control in real time the RFA procedure by turning off the power when temperature reached $45^{\circ} \mathrm{C}$. The knowledge of temperature evolution in real-time allowed the preservation of the vulnerable structures close to the tumor mass. Also, the same research group reported a study involving 31 patients suffering from spinal metastases treated with RFA [157]. In 
this case, temperature monitoring was performed by means of a thermocouple positioned at the level of the vertebra's posterior wall or into the epidural space. This study aimed at evaluating the efficacy of bipolar radiofrequency ablation with a target temperature of $70^{\circ} \mathrm{C}$. A study similar to [51] was carried out by the same research group in 2021 [158]. In this article, the authors suggested a combined technique of temperature monitoring and hydrodissection within the anterior epidural space in seven patients affected by thoracic metastases. To record temperature, authors used a thermocouple integrated into the RF probe. In all the procedures performed, temperature did not exceed $45^{\circ} \mathrm{C}$.

Table 1. Main benefits and drawbacks of thermometric techniques employed during HTs.

\begin{tabular}{|c|c|c|}
\hline $\begin{array}{c}\text { Thermometric } \\
\text { Techniques }\end{array}$ & Benefits & Drawbacks \\
\hline Thermocouples & $\begin{array}{l}\text { Low cost; small size; robustness; wide measurement } \\
\text { range; and short response time }\end{array}$ & $\begin{array}{l}\text { Invasive; single point measurement; metallic } \\
\text { composition; potential measurement artifacts }\end{array}$ \\
\hline Thermistors & $\begin{array}{l}\text { Low cost; small size; robustness; high sensitivity; } \\
\text { short response time; good accuracy }\end{array}$ & $\begin{array}{l}\text { Invasive; single point measurement; potential } \\
\text { measurement artifacts }\end{array}$ \\
\hline Fluoroptic sensors & $\begin{array}{l}\text { Biocompatibility; small size, immunity to } \\
\text { electromagnetic fields; wide measuring range; } \\
\text { high accuracy }\end{array}$ & $\begin{array}{l}\text { Invasive; single point measurement; fragility; } \\
\text { potential measurement artifacts }\end{array}$ \\
\hline FBGs & $\begin{array}{l}\text { Biocompatibility; small size; immunity to } \\
\text { electromagnetic fields; high accuracy; short response } \\
\text { time; multi-point temperature measurements; }\end{array}$ & $\begin{array}{l}\text { Invasive; fragility; cross-sensitivity to strain; } \\
\text { high-cost }\end{array}$ \\
\hline CT-thermometry & $\begin{array}{l}\text { Non-invasive; thermal map reconstruction; good } \\
\text { spatial resolution; fast acquisition time; temperature } \\
\text { precision around } 3^{\circ} \mathrm{C}\end{array}$ & $\begin{array}{l}\text { Ionizing radiation dose; potential measurement } \\
\text { artifacts; quite expensive }\end{array}$ \\
\hline US-thermometry & $\begin{array}{l}\text { Non-invasive; thermal map reconstruction; absence } \\
\text { of ionizing radiation; quite inexpensive }\end{array}$ & Potential measurement artifacts \\
\hline MR-thermometry & $\begin{array}{l}\text { Non-invasive; thermal map reconstruction; absence } \\
\text { of ionizing radiation; linear relationship between } \mathrm{T} 1 \\
\text { and temperature variations in the range of } 30^{\circ} \mathrm{C} \text { and } \\
70^{\circ} \mathrm{C} \text {; no tissue type dependence for PRF method }\end{array}$ & $\begin{array}{l}\text { Potential measurement artifacts; lack of MR signal in } \\
\text { cortical bone; expensive }\end{array}$ \\
\hline
\end{tabular}

Table 2 summarizes studies performing temperature monitoring during RFA in bone.

Table 2. Studies performing temperature monitoring in bone during RFA.

\begin{tabular}{cccc}
\hline $\begin{array}{c}\text { Authors, } \\
\text { Reference and Year }\end{array}$ & Type of Study & $\begin{array}{c}\text { Type of Sensors (Number of } \\
\text { Sensors) }\end{array}$ & Type of Probe \\
\hline Dupuy et al. [43], 2000 & Ex vivo and in vivo animal trial & Thermistors (3) & Monopolar RFA \\
\hline $\begin{array}{c}\text { Rachbauer et al. } \\
\text { [148], 2003 }\end{array}$ & Ex vivo trial & $\begin{array}{c}\text { Water-cooled single RF } \\
\text { electrode (Radionics } \\
\text { Instruments Inc.) }\end{array}$ \\
$\begin{array}{c}\text { Bitsch et al. [149], 2006 } \\
\text { Tdachi et al. [150], 2008 }\end{array}$ & Ex vivo trial & Thermocouples (3) & $\begin{array}{c}\text { Monopolar RF electrode } \\
\text { (TCM 101; Stryker Leibinger, } \\
\text { Freiburg, Germany) }\end{array}$ \\
\hline $\begin{array}{c}\text { Nakatuska et al. } \\
\text { [151], 2009 }\end{array}$ & Clinical trial & $\begin{array}{c}\text { K-type thermocouples (3 during } \\
\text { in vivo and 2 during ex vivo } \\
\text { experiments) }\end{array}$ & $\begin{array}{c}\text { 17G monopolar cooled } \\
\text { RF electrode }\end{array}$ \\
\hline
\end{tabular}


Table 2. Cont.

\begin{tabular}{|c|c|c|c|}
\hline $\begin{array}{c}\text { Authors, } \\
\text { Reference and Year }\end{array}$ & Type of Study & $\begin{array}{c}\text { Type of Sensors (Number of } \\
\text { Sensors) }\end{array}$ & Type of Probe \\
\hline Groetz et al. [152], 2013 & Ex vivo human trial & K-type thermocouples (3) & $\begin{array}{c}\text { RFA array electrode } \\
\text { (LeV-eenTM Electrode System, } \\
\text { Boston Scientific, Natick, USA) } \\
\text { Single-needle RFA electrode } \\
\text { (Soloist }^{\mathrm{TM}} \text { Electrode System, } \\
\text { Boston Scientific, } \\
\text { Natick, USA) }\end{array}$ \\
\hline Pezeshki et al. [153], 2014 & Ex vivo animal trial & Thermocouple (1) & $\begin{array}{l}\text { 17G bipolar cooled RF probe } \\
\text { (OsteoCool Baylis } \\
\text { Medical Company) }\end{array}$ \\
\hline $\begin{array}{l}\text { Greenberg at al. } \\
\text { [154], } 2014\end{array}$ & Ex vivo animal trial & Thermocouple (not defined) & $\begin{array}{c}\text { Monopolar RF probe } \\
\text { (ACT-1510 Cool-tip Ablation } \\
\text { System, Valley-lab, } \\
\text { Boulder, Colorado) }\end{array}$ \\
\hline $\begin{array}{l}\text { Bornemann et al. } \\
\text { [45], } 2016\end{array}$ & Ex vivo animal trial & K-type thermocouples (3) & $\begin{array}{c}\text { Monopolar RF probe } \\
\text { (SpineSTAR, DFINE Inc. San } \\
\text { Jose, CA, USA) }\end{array}$ \\
\hline $\begin{array}{l}\text { Bornemann et al. } \\
\text { [155], } 2016\end{array}$ & In vitro model & K-type thermocouples (3) & $\begin{array}{c}\text { Bipolar RF ablation electrode } \\
\text { (SpineSTAR, DFINE Inc. San } \\
\text { Jose, CA, USA) } \\
\text { Two monopolar RF electrodes } \\
\text { (Soloist and LeVeen, Boston } \\
\text { Scientific, Natick, MA, USA) }\end{array}$ \\
\hline Wei et al. [156], 2018 & $\begin{array}{l}\text { Ex vivo and in vivo } \\
\text { animal trials }\end{array}$ & $\begin{array}{l}\text { Not specified in ex vivo trial (2) } \\
\text { and thermistors in in vivo (3) }\end{array}$ & $\begin{array}{l}\text { Multipolar RFA (RFA-1315, } \\
\text { Beijing Bolai, Beijing, China) }\end{array}$ \\
\hline Lecigne et al. [51], 2019 & Clinical trial & Thermocouple (1) & $\begin{array}{c}\text { Bipolar RFA (OsteoCool } \\
\text { Medtronic/STAR } \\
\text { Merrit Medical) } \\
\text { Monopolar RFA } \\
\text { (OsteoCool Medtronic) }\end{array}$ \\
\hline Mayer et al. [157], 2021 & Clinical trial & Thermocouple (1) & $\begin{array}{c}\text { Bipolar RFA } \\
\text { (Osteocool medtronic) }\end{array}$ \\
\hline Lecigne et al. [158], 2021 & Clinical trial & Thermocouple (1) & $\begin{array}{c}\text { Monopolar RFA (Multigen } \\
\text { Stryker, USA) } \\
\text { Bipolar RFA (OsteoCool } \\
\text { Medtronic/STAR } \\
\text { Merrit Medical) }\end{array}$ \\
\hline
\end{tabular}

\subsection{Temperature Monitoring during LA in Bone}

In this subsection, the LA working principle and its first application in bone tumors will be briefly reported. After this introduction, studies referring to temperature monitoring during LA will be described in depth.

Basically, LA involves the use of a laser source and an optical fiber (around $200 \mu \mathrm{m}$ in diameter) which is responsible for carrying the light within the tissue. A monochromatic light is emitted at a specific wavelength by a laser. The wavelength employed attributes the laser properties and the manner of interaction with the tissue. Light-tissue interaction takes place through three different phenomena: scattering, reflection, and absorption [159]. The absorbed light is mainly converted into the heat. The amount of heat produced within the tissue is affected by several factors. Among others, there are the laser wavelength, laser working modality (i.e., continuous or pulsed), treatment time, input power, and physical and optical tissue properties [160]. Commonly employed systems consist of 
$980 \mathrm{~nm}$ diode laser and $1064 \mathrm{~nm}$ neodymium-doped yttrium aluminum garnet (Nd: YAG) which guarantee optimal absorption and penetration rate.

LA was firstly introduced for OO treatment in 1998 by Gangi et al. [161]. Later investigations carried out during a clinical trial can be found in the literature [11,162-164].

Only few studies investigated temperature monitoring during LA. In 2002, Binkert et al. [165] evaluated the possibility to monitor temperature in real-time with MR thermometry. Two pigs were subjected to LA, for a total of nine vertebrae treated. Nd: YAG system at an input power of $10 \mathrm{~W}$ and a treatment time of $2 \mathrm{~min}$ was employed to accomplish the procedure. MR-thermometry was carried out using the T1 method because of its good sensitivity in the presence of low electromagnetic field (in this study $0.5 \mathrm{~T}$ ) and its ability to track temperature in the spinal cord. In MR images, thermal necrosis was found since $20 \mathrm{~s}$ after applying energy and it could be observed by an increase in color brightness. Irreversible $\mathrm{T} 1$ signal changes were observed in the middle of the treated area, in the paraspinal muscle and in the spinal canal because of attaining cytotoxic temperatures. Thermal injuries in the spinal cord occurred in presence of cortical bone defects. In this study, authors demonstrated the potential of MR-thermometry to keep track of thermal injuries in the vertebral bodies and spinal canal. It is worth noting that the acquisition of thermal map was obtained only during apnea to avoid motion artifacts due to respiratory movements.

In [166], MRI scanner in a low-field configuration $(0.23 \mathrm{~T})$ was employed in five patients undergoing LA (Nd:YAG). Unlike previous studies, authors revealed an unreliable change in T1 relaxation time in response to temperature increment because of weak signal from cortical bone, accounting for the majority of the OO.

Few years later, Streitparth et al. [167] published results of a clinical trial involving one patient affected by OO. LA was carried out by Nd:YAG laser at $2.3 \mathrm{~W}$ of power and an operating time of $11 \mathrm{~min}$. Additionally, MRI scanner (1.0 T) was used as both guidance and to monitor T1 changes due to temperature increment. A commercially available software allowed displaying in real-time temperature map and tissue alterations. No further details regarding temperature values reached in the tumor or in the surrounding healthy structures were given in this investigation. Also, the same research group employed MR-thermometry based on T1 method with the aim to protect surrounding anatomical structures (i.e., joint cartilage) in patient affected by a recurrence of tibial OO [168].

A retrospective study conducted by Tatsui et al. [169], evaluated the feasibility of treating spinal tumors with LA. For this purpose, 11 tumors located in thoracic, lumbar, and cervical spine with epidural space involvement were treated with a 980-nm diode laser (at an input power of $30 \mathrm{~W}$ ). Temperature monitoring was accomplished by PRF method. An ad-hoc software allowed retrieving temperature values in each image's pixel. A control-algorithm enabled to stop energy delivery when the temperature between the epidural space and the dura mater exceeded $50^{\circ} \mathrm{C}$. This method prevented irreversible damage in structures such as spinal cord and nerve roots. Whereas breathing-related movements can affect temperature estimation, laser was switched on during apnea phase, thus avoiding possible artifacts in thermal map resulting from MR-thermometry. One year later, the method just described was used by the same research group on a larger cohort of patients (i.e., 19) affecting by spinal metastasis with epidural compression [170].

A brief summary of the studies performing temperature monitoring in bone during LA is provided in Table 3. 
Table 3. Scientific articles describing temperature monitoring during LA in bone.

\begin{tabular}{llll}
\hline \multicolumn{1}{c}{$\begin{array}{c}\text { Authors, } \\
\text { Reference and Year }\end{array}$} & Type of Study & Type of Technique & Type of Laser \\
\hline $\begin{array}{l}\text { Binkert et al. } \\
\text { [165], 2002 }\end{array}$ & In vivo animal trial & MR-thermometry & 1064 nm Nd:YAG \\
\hline $\begin{array}{l}\text { Sequeiros et al. } \\
{[166], \text { 2003 }}\end{array}$ & Clinical trial & MR-thermometry & 1064 nm Nd:YAG \\
\hline $\begin{array}{l}\text { Streitparth et al. } \\
{[167], \text { 2009 }}\end{array}$ & Clinical trial & MR-thermometry & 1064 nm Nd:YAG \\
\hline $\begin{array}{l}\text { Streitparth et al. } \\
{[168], 2010}\end{array}$ & Clinical trial & MR-thermometry & $1064 \mathrm{~nm}$ Nd:YAG \\
\hline $\begin{array}{l}\text { Tatsui et al. } \\
{[169], 2015}\end{array}$ & Clinical trial & MR-thermometry & $980 \mathrm{~nm}$ diode \\
\hline $\begin{array}{l}\text { Tatsui et al. } \\
{[170], 2016}\end{array}$ & Clinical trial & MR-thermometry & $980 \mathrm{~nm}$ diode \\
\hline
\end{tabular}

\subsection{Temperature Monitoring during MWA in Bone}

After a short introduction about MWA, this subsection will be devoted to describing studies performing temperature monitoring during MWA in bone.

During MWA, electromagnetic radiations (usually with a frequency of $915 \mathrm{MHz}$ or $2.45 \mathrm{GHz}$ ) are conveyed within the tissue by means of the so-called antenna. Dielectric heating occurs due to the interaction between water molecules and the applied field. So, in presence of an alternating field, dipoles revolve continuously to align with it. This phenomenon results in the production of frictional energy leading to temperature increment [171]. Compared to other HTs, MWA allows temperatures above $100{ }^{\circ} \mathrm{C}$, increased ablation volume and shorter treatment time.

The first scientific investigations on MWA in bone go back to 1996 [172,173]. Due to the encouraging results obtained in these works, MWA received broad clinical acceptance for the treatment of bone tumors $[28,29,174-177]$.

Studies concerning temperature monitoring during MWA in bone are lacking in the literature, and the few research articles found are quite recent.

In 2014, temperature monitoring was performed during MWA of spinal metastasis [178]. The study included seventeen patients, treating a total of twenty lesions. MW ablation system was set to deliver a power between $30 \mathrm{~W}$ and $70 \mathrm{~W}$, applied for a variable duration ranging from $1 \mathrm{~min}$ to $8 \mathrm{~min}$, depending on the lesion size. Only in four cases, a thermocouple was used to monitor in real-time temperature variations because of the proximity to neural structures. No additional details were given about temperature values recorded during the procedure.

A mention of temperature monitoring is also provided in [179]. In their study, authors cited the use of multiple thermocouples placed at critical anatomical sites to monitor temperature in and around the target area, during MWA in malignant bone tumors.

In [180], a thermocouple was used for temperature monitoring during MWA of bone metastases aiming at preventing irreversible thermal injury to nearby structures. At this purpose, a clinical trial involving 16 patients suffered from secondary bone tumors was carried out, for a total of 18 MWAs. The procedures were performed with an input power of either $15 \mathrm{~W}$ or $40 \mathrm{~W}$ and a treatment time ranging between $1 \mathrm{~min}$ and $6 \mathrm{~min}$. According to the cancer mass positioning (spinal column, rib and sternum), the thermocouple was placed in the following anatomical sites: epidural space, nerve roots, pleura (in case of rib ablation) and pericardium (during sternal ablation). In three procedures, more than one thermocouple was inserted in the treated area to control temperature in different neural structure' sites. In eight cases MWA was interrupted due to the occurrence of cytotoxic temperatures. 
For the first time, FBGs appeared for bone temperature monitoring purpose in [181]. MWA was carried out in ex vivo bovine bones (i.e., femur and tibia) setting a power of $75 \mathrm{~W}$ and ablation time of $8 \mathrm{~min}$. Temperature monitoring was accomplished by means of four fiber optics, each embedding $10 \mathrm{FBGs}$. Their use allowed measuring temperature in 40 different anatomical sites. Maximum temperature values (i.e., $63.2^{\circ} \mathrm{C}$ in case of femur ablation and $91.4{ }^{\circ} \mathrm{C}$ during tibia MW ablation) were recorded by one of the FBGs belonging to the optical fiber positioned closer to the MW antenna at the end of the treatment in both ablation procedures. In a post-processing phase, the multi-point temperature measurements allowed obtaining temperature map by a linear interpolation of the temperature data recorded during femur and tibia ablation. The resulting thermal maps helped to gain useful information regarding the heat distribution not only near the treated area but also in the surrounding ones. This work was the result of a deeply investigation after a preliminary assessment carried out by the same research group in shortly before [182].

Recently, a retrospective study carried out by Ke et al. [183] presented results obtained for 56 bone metastases underwent image guided MWA. One or more thermocouples were employed to monitor temperature in different anatomical sites. The use of these thermometers was intended as a control for ensuring temperature values below $43^{\circ} \mathrm{C}$ in healthy tissues.

A short summary of the applications related to temperature monitoring during MWA in bone is provided in Table 4.

Table 4. Studies related to temperature monitoring during bone MWA.

\begin{tabular}{|c|c|c|c|}
\hline $\begin{array}{c}\text { Authors, } \\
\text { Reference and Year }\end{array}$ & Type of Study & $\begin{array}{l}\text { Type of Sensors } \\
\text { (and Number) }\end{array}$ & Type of Source \\
\hline Kastler et al. [178], 2014 & Clinical trial & Thermocouple (1) & $\begin{array}{c}2.45 \mathrm{GHz}-\mathrm{MW} \text { generator } \\
\text { (Microsulis / AngioDynamics, Latham, } \\
\text { New York) and } 14 \mathrm{~cm} \text { or } 19 \mathrm{~cm} \text { long of } \\
\text { MW antenna. }\end{array}$ \\
\hline Fan et al. [179], 2016 & Clinical trial & Thermocouples (not specified) & $\begin{array}{l}2.45 \mathrm{GHz} \text { MW generator and co-axial } \\
\text { antenna (no further details provided). }\end{array}$ \\
\hline Kastler et al. [180], 2017 & Clinical trial & $\begin{array}{c}\text { Thermocouples ( } 1 \\
\text { or more than one in } 3 \text { cases) }\end{array}$ & $\begin{array}{l}2.45 \mathrm{GHz}-\mathrm{MW} \text { generator } \\
\text { (AngioDynamics, Inc, Latham, New } \\
\text { York) or Amica (Hospital Service, } \\
\text { Rome, Italy). Details about the antenna } \\
\text { used were not specified. }\end{array}$ \\
\hline De Vita et al. [181], 2020 & Ex vivo animal trial & FBGs (40) & $\begin{array}{l}2.45 \mathrm{GHz}-\mathrm{MW} \text { generator and } 15 \mathrm{~cm} \\
\text { long antenna with an active tip of } \\
31 \mathrm{~mm} \text { (Microwave Ablation System, } \\
\text { Surgnova Healthcare } \\
\text { Technologies, Zhejiang) }\end{array}$ \\
\hline De Tommasi et al. [182], 2020 & Ex vivo animal trial & FBGs (30) & $\begin{array}{c}2.45 \mathrm{GHz}-\mathrm{MW} \text { generator and } 15 \mathrm{~cm} \\
\text { long antenna with an active tip of } \\
31 \mathrm{~mm} \text { (Microwave Ablation System, } \\
\text { Surgnova Healthcare } \\
\text { Technologies, Zhejiang) }\end{array}$ \\
\hline
\end{tabular}

\subsection{Temperature Monitoring during HIFU in Bone}

In this subsection we will give a quick description of the HIFU's working principle and then we will describe studies performing temperature monitoring during HIFU ablation in bone.

Differently from the previously described techniques, HIFU ablation does not require surgical incision or needlelike probe insertion for the treatment of tumor masses. It involves the use of high-focused ultrasound (frequencies ranging between $0.2 \mathrm{MHz}$ and $3.5 \mathrm{MHz}$ ) converging in a specific point (i.e., focal point) where the energy is highly concentrated by 
means of a transducer. The energy conveyed is able to promote irreversible biological tissue damage within the focal point, because of temperature raising at cytotoxic levels [184]. A feasibility assessment about the efficacy of HIFU for the treatment of primary or secondary bone tumors appears in 2001 [185]. Despite its late application in bone tumors, multiple studies showed promising results concerning the application of HIFU in this hard tissue [33,35,186-190].

Other relevant studies have also explored temperature monitoring using MRthermometry. A mention of thermal maps acquired during MR-guided HIFU ablation of OO can be found in [191].

In [192], an investigation was carried out to evaluate the temperature dependence of cortical bone tissue during MR-guided HIFU ablation. In a first phase, experiments were carried out in ex vivo beef shanks to preliminary assess temperature changes in cortical bone under MRI. At this purpose, bone tissue was heated in a hot water bath and after subjected to MR-scanner (3.0 T and a short TE gradient echo imaging sequence) to record temperature changes during the cooling phase. Fiber optic sensors previously inserted in cortical bone was used as reference system. Phase image changes were fitted with temperature recorded from fiber optic sensors, showing a good correlation between the two set of data $\left(\mathrm{R}^{2}>0.85\right)$. A subsequently evaluation consisted of MR-HIFU (1.2 MHz transducer) of an ex vivo beef shank immersed in a gum phantom. Once again, four fiber optics placed inside the cortical bone were used to assess the reliability of temperature data estimated by PRF method during MRI. In a post-processing phase, thermal map of bone tissue was also derived by means of a dual echo approach (i.e., short and long echo acquisition) to obtain temperature information about both bone and soft tissue.

Lam et al. [193] evaluated the performance of PRF shift method during a clinical trial enrolling eleven patients subjected to HIFU treatment in bone (i.e., osteolytic, osteoblastic and mixed lesions). This study aimed at assessing the image quality in terms of signalto-noise-ratio (hereafter SNR) and temperature variations resulting from phase image changes and to score artifacts derived from: field inhomogeneities, arterial ghosting and patient motion. Each treatment was carried out with variable treatment settings (i.e., power ranging from $20 \mathrm{~W}$ and $50 \mathrm{~W}$ and time between $16 \mathrm{~s}$ and $20 \mathrm{~s}$ ) and $1.5 \mathrm{~T}-\mathrm{MR}$ scanner. Results revealed a highest SNR in case of osteolytic lesions and a maximum temperature variation up to $1.8^{\circ} \mathrm{C}$ in mixed lesions. About artifacts, field inhomogeneities related to breathing was found to be the most dominant, thus resulting in a potential temperature offset.

In [194] T2-based thermometry was used to measure temperature variation in the spinal cord of ex vivo and in vivo bovine bone during MR-HIFU ablation. After a temperature calibration process, two ex vivo bovine femur were cut to expose the trabecular tissue to the ultrasound beam. HIFU system worked at a frequency of $500 \mathrm{kHz}$ and an acoustic power of $17.6 \mathrm{~W}$ for a treatment duration of $8 \mathrm{~min}$. Three fiber optic sensors were inserted inside the spinal cord as reference system. T2 values were measured in three different ROI (i.e., in correspondence of the fiber optics tips). Another ex vivo experiment consisted of HIFU ablation (1.15 MHz-transducer, acoustic power of $30 \mathrm{~W}$ and sonication time of $20 \mathrm{~s}$ ) in an intact ex vivo swine femur to mimic the real condition. HIFU ablation was also performed in in vivo swine model. For each of these experiments, thermal tissue map was retrieved. Despite in all cases the focal point was conveyed within the bone marrow, in ex vivo trabecular ablation, the high temperature values were recorded in bone tissue because of its high ultrasound absorption rate. Also, a linear relationship between temperature values recorded by the fiber optic and the T2 changes was found in the heating process. For intact ex vivo ablation, an increment of T2 values was obtained in the marrow. Finally, for in vivo test the maximum $\mathrm{T} 2$ value was recorded at the end of the treatment and a value of $231 \mathrm{~ms}$ was found in the bone marrow corresponding to a temperature variation of $33^{\circ} \mathrm{C}$.

In [195], nine patients affected by OO were treated with MR-HIFU ablation. The ablation system consisted of an ultrasound transducer and 1.5 T MR-scanner. Treatment settings were changeable according to the lesion size. MR-thermometry in the affected tissue portion and in the closest tissues were carried out to ensure the safety of the procedure. 
Thermal maps resulting from the procedures evidenced similar temperature values in the surrounding anatomical structures and no tissue heating occurred beyond pre-planned treatment margins.

Study published by Guillemin et al. [196] consisted of a MR-guided HIFU procedure in an ex vivo animal tibia drilled to mimic osteolytic tumor mass. Experiments were performed with an acoustic power of $60 \mathrm{~W}$ and temperature monitoring in tissue adjacent to the periosteum was accomplished with the PRF shift method employing a 3T MR-scanner. Due to the lack of MR-signal in cortical bone, temperature in this anatomical structure was monitored by means of a fluoroptic sensor positioned inside it after drilling. Experiments were carried out resembling different focal point positioning (i.e., inside the medullar cavity, in front of the medullar cavity and in the cortical breakthrough). Procedure's safety was evaluated by matching data retrieved from MR-thermometry and fluoroptic sensors. A predictive temperature model was developed to tune the acoustical energy deposition automatically with the aim of controlling temperature rise at the focal point. Finally, a numerical simulation allows estimating the time delay between the energy application and the temperature rise at the focal point.

In [197], authors demonstrated the possibility to monitor temperature in water and fat in the treatment of bone lesions during MR-guided HIFU. MR-thermometry was conducted using alternately the PRF and T1 methods. The proposed solution was evaluated both in ex vivo swine leg and in a healthy volunteer without heating conditions. Thermal maps gained allow obtaining temperature information in water and fat voxels by overlapping information obtained from PRF and T1 thermometry. Thus, providing information in districts surrounding the bone and not limited to the treated portion.

Table 5 summarizes studies performing temperature monitoring during HIFU in bone.

Table 5. Studies related to temperature monitoring during HIFU ablation in bone.

\begin{tabular}{|c|c|c|c|}
\hline $\begin{array}{c}\text { Authors, } \\
\text { Reference and Year }\end{array}$ & Type of Study & Type of Techniques & Type of Source \\
\hline Geiger et al. [191], 2014 & Clinical trial & MR-thermometry & $\begin{array}{c}\text { ExAblate } 2100 \text { MR-guided } \\
\text { focused ultrasound system } \\
\text { (InSightec, Tirat Carmel, Israel) }\end{array}$ \\
\hline Ramsay et al. [192], 2015 & Clinical trial & $\begin{array}{l}\text { MR-thermometry } \\
\text { and } 4 \text { fiber optics }\end{array}$ & 1.2 MHz-transducer \\
\hline Lam et al. [193], 2016 & Clinical trial & MR-thermometry & Not specified \\
\hline Ozhinspky et al. [194], 2016 & $\begin{array}{l}\text { Ex vivo and in vivo } \\
\text { animal trial }\end{array}$ & $\begin{array}{l}\text { MR-thermometry } \\
\text { and } 3 \text { fiber optics }\end{array}$ & $\begin{array}{c}\text { Ultrasound system operating at } \\
500 \mathrm{kHz} \text { (ExAblate 2100, } \\
\text { InSightec, Israel) }\end{array}$ \\
\hline Sharma et al. [195], 2017 & Clinical trial & MR-thermometry & $\begin{array}{l}\text { Ultrasound system Sonalleve } \\
\text { V2 (Philips, Vantaa, Finland) }\end{array}$ \\
\hline Guillemin et al. [196], 2019 & Ex vivo animal trial & $\begin{array}{l}\text { MR-thermometry } \\
\text { and } 1 \text { fluoroptic sensor }\end{array}$ & $\begin{array}{l}\text { Phased array HIFU transducer } \\
\text { (Imasonic, Besançon, France) }\end{array}$ \\
\hline Lena et al. [197] & Ex vivo and in vivo trials & MR-thermometry & $\begin{array}{l}\text { HIFU Platform (Sonalleve } \\
\text { MR-HIFU V2; Profound } \\
\text { Medical, Mississauga, ON, } \\
\text { Canada Mississauga, } \\
\text { ON, Canada) }\end{array}$ \\
\hline
\end{tabular}

\section{Discussions and Conclusions}

In the last decades, HTs are gaining momentum in bone malignancy management because of both encouraging results in terms of pain relief affecting a wide cohort of patients and indisputable advantages of these minimally invasive techniques. It is worth noting that among innovative areas of research involving HTs, its use in synergy with conventional treatments (e.g., chemotherapy or radiotherapy) may overcome one of the 
most important concerns of HTs which is the incomplete tumor destruction [198]. In this scenario, temperature monitoring may be beneficial to enhance abscopal effects which have shown promising results in advanced cancers [199-201].

During bone ablations and more generally in such kind of treatments, one of the major pitfalls concerns either the prediction or the real time knowledge of the effects. Thermal injury occurs because of the existence of cytotoxic temperatures inside the tissue and exposure time. Thus, temperature tissue monitoring may be helpful to ensure the complete tumor destruction while sparing healthy anatomical structures. This aspect deserves special attention in bone malignancies owing to the presence of vulnerable structures (i.e., spinal cord and nerve roots). Indeed, temperatures above $45^{\circ} \mathrm{C}$ would be neurotoxic for such structures and could potentially lead to permanent impairment. In the light of above, in this work, we focused on the potential of temperature monitoring during bone HTs. Studies investigating temperature measurements in bone were reviewed and reported according to the specific HT employed (i.e., RFA, LA, MWA and HIFU). Pre-clinical and clinical studies were found to explore the applicability of specific thermometric techniques tailored to this specific scenario. Among contact-based and contactless techniques used to record temperature during HTs, only some of them were adopted in this specific context. Thermocouples, thermistors, and MR-thermometry play a leading role during HTs in bone. Very few studies addressed the potential of FBGs for temperature measurements purposes during bone ablation, despite their popularity in other hyperthermia applications. Otherwise, fluoroptic sensors were only used in the validation of MR-thermometry during bone HIFU procedures. To the best of our knowledge, to date, literature lacks investigations regarding $\mathrm{CT}$ and ultrasound thermometry in bone ablation. From non-exhaustive inferences, contactless techniques could be expected preferably in bone ablation context where preserving vulnerable structures is a priority. Unfortunately, despite this category of techniques is capable of reconstructing temperature tissue map, it is not immune to drawbacks which severely limits its use. Of course, the use of sophisticated algorithms to estimate temperature and the high costs of diagnostic imaging techniques are two of the negative issues to noteworthy. In case of CT-thermometry the radiation dose is another aspect to be kept in mind. Furthermore, contactless thermometry is affected by measurement artefacts due to patients' movements, especially those due to breathing, hence the need to implement alternative solutions to overcome this concern (e.g., signal acquisition during breathing holding, algorithms devoted to artifact removal). In the specific case of MR-thermometry in bone, it should be pointed out the lack of MR-signal in cortical bone which may lead to unreliable and inaccurate temperature measurements. Unexpected, contact-based techniques are so far well suited to the context. The broad implementation of transducers such as thermocouples and thermistors are mainly due to their low cost, small size, robustness, wide measuring range, short response time and ease to use which make them preferable to other techniques involving a high level of expertise. Despite their invasiveness, many studies exploring temperature monitoring in bone employed such kind of solution offering the right balance between affordability and reliability. Also, the use of these techniques overcomes the issue of breathing-related artifacts. On the other hand, thermocouples and thermistors provide a single-point measurement, thus it is not feasible to obtain temperature map for estimating thermal tissue damage. Moreover, owing to their metallic composition, these thermometers cannot work in presence of high electromagnetic fields (e.g., MR). Although FBGs are currently lacking special attention in the field of bone ablation, they appear very promising in this arena because of their countless features, among others biocompatibility, small size, immunity to electromagnetic fields, wide measuring range and high sensitivity. A special mention deserves their multiplexing capability which allows temperature measurements in several point with high resolution (even less than $1 \mathrm{~mm}$ ) and an accuracy around $0.1^{\circ} \mathrm{C}$ (but strongly dependent to the quality of the interrogator system). Thus, it is possible to obtain reliable temperature map which is the key aspect especially in this specific context where incorrect estimation could lead to irreversible injuries in healthy susceptible areas. 
Summing up, from an overview of bone temperature monitoring, the studies found corroborated the importance of this key aspect during bone HTs. Most of these studies aimed at assessing tissue thermal response (e.g., in cortical bone, epidural space, bone marrow) and preventing permanent damage in vulnerable structures, which represents the most challenging aspect of this scenario. Other works investigated the suitability of specific thermometric techniques in monitoring and predicting temperature under particular settings. Only some explored the performances of specific devices in terms of enhancement in safety and clinical outcomes improvement. However, despite many investigations were performed during clinical trials, nowadays, temperature monitoring during bone ablation is still severely restricted in clinical settings. In our view, substantial research efforts are still necessary for making practical some technologies in medical scenarios where clinicians may benefit of being led by real-time temperature knowledge during the procedures without being forced to alter their clinical practice.

Author Contributions: Conceptualization, F.D.T., R.F.G., M.C. and E.S.; methodology, F.D.T., C.M. and E.S.; investigation, F.D.T., C.M., R.F.G., M.C. and E.S; resources, C.M. and E.S.; writing-original draft preparation, F.D.T., E.S.; writing-review and editing, F.D.T., C.M., R.F.G., M.C. and E.S.; supervision, M.C., E.S. All authors have read and agreed to the published version of the manuscript.

Funding: This research received no external funding.

Institutional Review Board Statement: Not applicable.

Informed Consent Statement: Not applicable.

Data Availability Statement: Not applicable.

Conflicts of Interest: The authors declare no conflict of interest.

$\begin{array}{ll}\text { Abbreviations } \\ \text { The following abbreviations are used in the manuscript: } \\ \text { OO } \quad \text { Osteoid osteoma } \\ \text { HT } & \text { Hyperthermia treatments } \\ \text { RFA } & \text { Radiofrequency ablation } \\ \text { LA } & \text { Laser ablation } \\ \text { MWA } & \text { Microwave ablation } \\ \text { CT } & \text { Computed tomography } \\ \text { MR } & \text { Magnetic resonance } \\ \text { HIFU } & \text { High intensity focused ultrasound } \\ \text { CEM } & \text { Cumulative equivalent minutes } \\ \text { FBG } & \text { Fiber Bragg grating sensors } \\ \text { emf } & \text { Electromotive force } \\ \text { PTC } & \text { Positive temperature coefficient } \\ \text { NTC } & \text { Negative temperature coefficient } \\ \text { HU } & \text { Hounsfield unit } \\ \text { PRF } & \text { Proton Resonance Frequency } \\ \text { TE } & \text { Echo time } \\ \text { RF } & \text { Radiofrequency }\end{array}$

\section{References}

1. Ferlay, J.; Soerjomataram, I.; Dikshit, R.; Eser, S.; Mathers, C.; Rebelo, M.; Parkin, D.M.; Forman, D.; Bray, F. Cancer incidence and mortality worldwide: Sources, methods and major patterns in GLOBOCAN 2012. Int. J. Cancer 2015, 136, E359-E386. [CrossRef] [PubMed]

2. Nielsen, O.S.; Munro, A.J.; Tannock, I.F. Bone metastases: Pathophysiology and management policy. J. Clin. Oncol. 1991, 9, 509-524. [CrossRef] [PubMed]

3. Nazario, J.; Hernandez, J.; Tam, A.L. Thermal ablation of painful bone metastases. Tech. Vasc. Interv. Radiol. 2011, 14, 150-159. [CrossRef]

4. Quattrocchi, C.C.; Piciucchi, S.; Sammarra, M.; Santini, D.; Vincenzi, B.; Tonini, G.; Grasso, R.F.; Zobel, B.B. Bone metastases in breast cancer: Higher prevalence of osteosclerotic lesions. Radiol. Med. 2007, 112, 1049-1059. [CrossRef] [PubMed] 
5. Ibrahim, T.; Flamini, E.; Mercatali, L.; Sacanna, E.; Serra, P.; Amadori, D. Pathogenesis of osteoblastic bone metastases from prostate cancer. Cancer Interdiscip. Int. J. Am. Cancer Soc. 2010, 116, 1406-1418. [CrossRef] [PubMed]

6. Tsuya, A.; Fukuoka, M. Bone metastases in lung cancer. Clin. Calcium 2008, 18, 455-459. [CrossRef]

7. Greenspan, A. Benign bone-forming lesions: Osteoma, osteoid osteoma, and osteoblastoma. Skelet. Radiol. 1993, 22, 485-500. [CrossRef] [PubMed]

8. Kransdorf, M.J.; Stull, M.A.; Gilkey, F.W.; Moser, R.P., Jr. Osteoid osteoma. Radiographics 1991, 11, 671-696. [CrossRef]

9. Gomez, J.A.O. The incidence of vertebral body metastases. Int. Orthop. 1995, 19, 309-311.

10. Sciubba, D.M.; Gokaslan, Z.L. Diagnosis and management of metastatic spine disease. Surg. Oncol. 2006, 15, 141-151. [CrossRef]

11. Gangi, A.; Alizadeh, H.; Wong, L.; Buy, X.; Dietemann, J.L.; Roy, C. Osteoid osteoma: Percutaneous laser ablation and follow-up in 114 patients. Radiology 2007, 242, 293-301. [CrossRef] [PubMed]

12. Smith, H.S. Painful Osseous Metastases. Pain Physician 2011, 14, 373-403. [CrossRef] [PubMed]

13. Ripamonti, C.; Fulfaro, F. Malignant bone pain: Pathophysiology and treatments. Curr. Rev. Pain 2000, 4, 187-196. [CrossRef]

14. Tomasian, A.; Jennings, J.W. Percutaneous minimally invasive thermal ablation for management of osseous metastases: Recent advances. Int. J. Hyperth. 2019, 36, 3-12. [CrossRef]

15. Hristov, B.; Shokek, O.; Frassica, D.A. The role of radiation treatment in the contemporary management of bone tumors. J. Natl. Compr. Cancer Netw. 2007, 5, 456-466. [CrossRef]

16. Healey, J.H.; Brown, H.K. Complications of bone metastases: Surgical management. Cancer Interdiscip. Int. J. Am. Cancer Soc. 2000, 88, 2940-2951. [CrossRef]

17. Fourney, D.R.; Frangou, E.M.; Ryken, T.C.; DiPaola, C.P.; Shaffrey, C.I.; Berven, S.H.; Bilsky, M.H.; Harrop, J.S.; Fehlings, M.G.; Boriani, S. Spinal instability neoplastic score: An analysis of reliability and validity from the spine oncology study group. J. Clin. Oncol. 2011, 29, 3072-3077. [CrossRef] [PubMed]

18. Frassica, D.A. General Principles of External Beam Radiation Therapy for Skeletal Metastases. Clin. Orthop. Relat. Res. 2003, 158-164. [CrossRef] [PubMed]

19. Rosenthal, D.; Callstrom, M.R. Critical review and state of the art in interventional oncology: Benign and metastatic disease involving bone. Radiology 2012, 262, 765-780. [CrossRef]

20. Moynagh, M.R.; Kurup, A.N.; Callstrom, M.R. Thermal Ablation of Bone Metastases. Semin. Intervent. Radiol. 2018, 35, 299-308. [CrossRef]

21. Ringe, K.I.; Panzica, M.; Von Falck, C. Thermoablation of Bone Tumors. In RoFo Fortschritte auf dem Gebiet der Rontgenstrahlen und der Bildgebenden Verfahren; Georg Thieme Verlag: New York, NY, USA, 2016; Volume 188, pp. 539-550.

22. Tomasian, A.; Jennings, J.W. Percutaneous Minimally Invasive Thermal Ablation of Osseous Metastases: Evidence-Based Practice Guidelines. Am. J. Roentgenol. 2020, 215, 502-510. [CrossRef]

23. Heymann, D. Bone Cancer. 2020. Available online: https://www.nccn.org/patientresources/patient-resources /guidelines-forpatients/guidelines-for-patients-details?patientGuidelineId=51 (accessed on 5 August 2021).

24. Goldberg, S.N.; Gazelle, G.S.; Mueller, P.R. Thermal Ablation Therapy for Focal Malignancy. Am. J. Roentgenol. 2000, $174,323-331$. [CrossRef]

25. Palussière, J.; Pellerin-Guignard, A.; Descat, E.; Cornélis, F.; Dixmérias, F. Radiofrequency ablation of bone tumours. Diagn. Interv. Imaging 2012, 93, 680-684. [CrossRef] [PubMed]

26. Goetz, M.P.; Callstrom, M.R.; Charboneau, J.W.; Farrell, M.A.; Maus, T.P.; Welch, T.J.; Wong, G.Y.; Sloan, J.A.; Novotny, P.J.; Petersen, I.A. Percutaneous image-guided radiofrequency ablation of painful metastases involving bone: A multicenter study. $J$. Clin. Oncol. 2004, 22, 300-306. [CrossRef]

27. Gangi, A.; Basille, A.; Buy, X.; Alizadeh, H.; Sauer, B.; Bierry, G. Radiofrequency and laser ablation of spinal lesions. Semin. Ultrasound CT MRI 2005, 26, 89-97. [CrossRef]

28. Cazzato, R.L.; de Rubeis, G.; de Marini, P.; Dalili, D.; Koch, G.; Auloge, P.; Garnon, J.; Gangi, A. Percutaneous microwave ablation of bone tumors: A systematic review. Eur. Radiol. 2021, 31, 3530-3541. [CrossRef]

29. Pusceddu, C.; Sotgia, B.; Fele, R.M.; Melis, L. Treatment of bone metastases with microwave thermal ablation. J. Vasc. Interv. Radiol. 2013, 24, 229-233. [CrossRef] [PubMed]

30. Ahmed, M.; Brace, C.L.; Lee, F.T.; Goldberg, S.N. Principles of and advances in percutaneous ablation. Radiology 2011, 258, 351-369. [CrossRef] [PubMed]

31. Goldberg, S.N.; Grassi, C.J.; Cardella, J.F.; Charboneau, J.W.; Dodd, G.D.; Dupuy, D.E.; Gervais, D.; Gillams, A.R.; Kane, R.A.; Lee, F.T.; et al. Image-guided tumor ablation: Standardization of terminology and reporting criteria. Radiology 2005, 235, 728-739. [CrossRef]

32. Leslie, T.A.; Kennedy, J.E. High-intensity focused ultrasound principles, current uses, and potential for the future. Ultrasound Q. 2006, 22, 263-272. [CrossRef]

33. Gianfelice, D.; Gupta, C.; Kucharczyk, W.; Bret, P.; Havill, D.; Clemons, M. Palliative treatment of painful bone metastases with MR imaging-guided focused ultrasound. Radiology 2008, 249, 355-363. [CrossRef]

34. Napoli, A.; Mastantuono, M.; Cavallo Marincola, B.; Anzidei, M.; Zaccagna, F.; Moreschini, O.; Passariello, R.; Catalano, C. Osteoid osteoma: MR-guided focused ultrasound for entirely noninvasive treatment. Radiology 2013, 267, 514-521. [CrossRef] 
35. Huisman, M.; Lam, M.K.; Bartels, L.W.; Nijenhuis, R.J.; Moonen, C.T.; Knuttel, F.M.; Verkooijen, H.M.; van Vulpen, M.; van den Bosch, M.A. Feasibility of volumetric MRI-guided high intensity focused ultrasound (MR-HIFU) for painful bone metastases. J. Ther. Ultrasound 2014, 2, 1-10. [CrossRef]

36. Bing, F.; Vappou, J.; de Mathelin, M.; Gangi, A. Targetability of osteoid osteomas and bone metastases by MR-guided high intensity focused ultrasound (MRgHIFU). Int. J. Hyperth. 2018, 35, 471-479. [CrossRef] [PubMed]

37. Pearce, J.A. Models for thermal damage in tissues: Processes and Applications. Crit. Rev. Biomed. Eng. 2010, 38, 1-20. [CrossRef] [PubMed]

38. Kok, H.P.; Cressman, E.N.K.; Ceelen, W.; Brace, C.L.; Ivkov, R.; Grüll, H.; ter Haar, G.; Wust, P.; Crezee, J. Heating technology for malignant tumors: A review. Int. J. Hyperth. 2020, 37, 711-741. [CrossRef]

39. Saccomandi, P.; Schena, E.; Silvestri, S. Techniques for temperature monitoring during laser-induced thermotherapy: An overview. Int. J. Hyperth. 2013, 29, 609-619. [CrossRef] [PubMed]

40. Lepetit-Coiffé, M.; Laumonier, H.; Seror, O.; Quesson, B.; Sesay, M.-B.; Moonen, C.T.W.; Grenier, N.; Trillaud, H. Real-time monitoring of radiofrequency ablation of liver tumors using thermal-dose calculation by MR temperature imaging: Initial results in nine patients, including follow-up. Eur. Radiol. 2010, 20, 193-201. [CrossRef]

41. Toupin, S.; Bour, P.; Lepetit-Coiffé, M.; Ozenne, V.; de Senneville, B.D.; Schneider, R.; Vaussy, A.; Chaumeil, A.; Cochet, H.; Sacher, F; et al. Feasibility of real-time MR thermal dose mapping for predicting radiofrequency ablation outcome in the myocardium in vivo. J. Cardiovasc. Magn. Reson. 2017, 19, 1-12. [CrossRef]

42. Lorber, G.; Glamore, M.; Doshi, M.; Jorda, M.; Morillo-Burgos, G.; Leveillee, R.J. Long-term oncologic outcomes following radiofrequency ablation with real-time temperature monitoring for T1a renal cell cancer. In Urologic Oncology: Seminars and Original Investigations; Elsevier: Amsterdam, The Netherlands, 2014; Volume 32, pp. 1017-1023.

43. Dupuy, D.E.; Hong, R.; Oliver, B.; Goldberg, S.N. Radiofrequency ablation of spinal tumors: Temperature distribution in the spinal canal. Am. J. Roentgenol. 2000, 175, 1263-1266. [CrossRef]

44. Tomasian, A.; Jennings, J.W. Vertebral Metastases: Minimally Invasive Percutaneous Thermal Ablation. Tech. Vasc. Interv. Radiol. 2020, 23, 100699. [CrossRef]

45. Bornemann, R.; Grötz, S.F.; Pennekamp, P.H.; Wilhelm, K.E.; Sander, K.; Wirtz, D.C.; Pflugmacher, R. Radiofrequency Ablation: Temperature Distribution in Adjacent Tissues. Z. Orthop. Unfall. 2016, 154, 294-298. [CrossRef]

46. Tsoumakidou, G.; Buy, X.; Garnon, J.; Enescu, J.; Gangi, A. Percutaneous thermal ablation: How to protect the surrounding organs. Tech. Vasc. Interv. Radiol. 2011, 14, 170-176. [CrossRef] [PubMed]

47. Nakatsuka, A.; Yamakado, K.; Maeda, M.; Yasuda, M.; Akeboshi, M.; Takaki, H.; Hamada, A.; Takeda, K. Radiofrequency ablation combined with bone cement injection for the treatment of bone malignancies. J. Vasc. Interv. Radiol. 2004, 15, 707-712. [CrossRef] [PubMed]

48. Gangi, A.; Tsoumakidou, G.; Buy, X.; Quoix, E. Quality improvement guidelines for bone tumour management. Cardiovasc. Intervent. Radiol. 2010, 33, 706-713. [CrossRef]

49. Garnon, J.; Cazzato, R.L.; Caudrelier, J.; Nouri-Neuville, M.; Rao, P.; Boatta, E.; Ramamurthy, N.; Koch, G.; Gangi, A. Adjunctive Thermoprotection During Percutaneous Thermal Ablation Procedures: Review of Current Techniques. Cardiovasc. Intervent. Radiol. 2019, 42, 344-357. [CrossRef]

50. Rybak, L.D.; Gangi, A.; Buy, X.; Vieira, R.L.R.; Wittig, J. Thermal ablation of spinal osteoid osteomas close to neural elements: Technical considerations. Am. J. Roentgenol. 2010, 195, 293-298. [CrossRef] [PubMed]

51. Lecigne, R.; Garnon, J.; Cazzato, R.L.; Auloge, P.; Dalili, D.; Koch, G.; Gangi, A. Transforaminal insertion of a thermocouple on the posterior vertebral wall combined with hydrodissection during lumbar spinal radiofrequency ablation. Am. J. Neuroradiol. 2019, 40, 1786-1790. [CrossRef]

52. Figliola, R.S.; Beasley, D.E. Theory and Design for Mechanical Measurements, 2nd ed.; John Wiley \& Sons: Hoboken, NJ, USA, 1995; Volume 20, ISBN 1119723450.

53. Warren, S.L. Preliminary study of the effect of artificial fever upon hopeless tumor cases. Am. J. Roentgenol. 1935, $33,75-87$.

54. Carnochan, P.; Dickinson, R.J.; Joiner, M.C. The practical use of thermocouples for temperature measurement in clinical hyperthermia. Int. J. Hyperth. 1986, 2, 1-19. [CrossRef]

55. Schena, E.; Giurazza, F.; Massaroni, C.; Fong, Y.; Park, J.J.; Saccomandi, P. Thermometry based on computed tomography images during microwave ablation: Trials on ex vivo porcine liver. In Proceedings of the 2017 IEEE International Instrumentation and Measurement Technology Conference (I2MTC), Turin, Italy, 22-25 May 2017; pp. 1-6.

56. Zhi-Yu, H.; Ping, L.; Xiao-Ling, Y.; Zhi-Gang, C.; Fang-Yi, L.; Jie, Y. A clinical study of thermal monitoring techniques of ultrasound-guided microwave ablation for hepatocellular carcinoma in high-risk locations. Sci. Rep. 2017, 7, 1-8. [CrossRef]

57. Ogan, K.; Roberts, W.W.; Wilhelm, D.M.; Bonnell, L.; Leiner, D.; Lindberg, G.; Kavoussi, L.R.; Cadeddu, J.A. Infrared thermography and thermocouple mapping of radiofrequency renal ablation to assess treatment adequacy and ablation margins. Urology 2003, 62, 146-151. [CrossRef]

58. Yu, J.; Liang, P.; Yu, X.; Liu, F.; Chen, L.; Wang, Y. A comparison of microwave ablation and bipolar radiofrequency ablation both with an internally cooled probe: Results in ex vivo and in vivo porcine livers. Eur. J. Radiol. 2009, 79, 124-130. [CrossRef] [PubMed]

59. Sun, Y.; Cheng, Z.; Dong, L.; Zhang, G.; Wang, Y.; Liang, P. Comparison of temperature curve and ablation zone between 915- and 2450-MHz cooled-shaft microwave antenna: Results in ex vivo porcine livers. Eur. J. Radiol. 2012, 81, 553-557. [CrossRef] 
60. Matsumoto, R.; Selig, A.M.; Colucci, V.M.; Jolesz, F.A. Interstitial Nd: YAG laser ablation in normal rabbit liver: Trial to maximize the size of laser-induced lesions. Lasers Surg. Med. 1992, 12, 650-658. [CrossRef] [PubMed]

61. Wren, J.; Loyd, D. Thermocouples; Wiley Online Library: Hoboken, NJ, USA, 2006.

62. Manns, F.; Milne, P.J.; Gonzalez-Cirre, X.; Denham, D.B.; Parel, J.-M.; Robinson, D.S. In Situ temperature measurements with thermocouple probes during laser interstitial thermotherapy (LITT): Quantification and correction of a measurement artifact. Lasers Surg. Med. 1998, 23, 94-103. [CrossRef]

63. Schena, E.; Majocchi, L. Assessment of temperature measurement error and its correction during Nd: YAG laser ablation in porcine pancreas. Int. J. Hyperth. 2014, 30, 328-334. [CrossRef]

64. Becker, J.A.; Green, C.B.; Pearson, G.L. Properties and uses of thermistors-Thermally sensitive resistors. Electr. Eng. 1946, 65, 711-725. [CrossRef]

65. Bowman, R.R. A probe for measuring temperature in radiofrequency heated material. IEEE Trans. Microw. Technol. Tech. 1976, 24, 43-45. [CrossRef]

66. Sturesson, C.; Ivarsson, K.; Andersson-Engels, S.; Tranberg, K.G. Changes in local hepatic blood perfusion during interstitial laser-induced thermotherapy of normal rat liver measured by interstitial laser Doppler flowmetry. Lasers Med. Sci. 1999, 14, 143-149. [CrossRef] [PubMed]

67. Dickson, J.A.; McKenzie, A.; McLeod, K. Temperature gradients in pigs during whole-body hyperthermia at 42 degrees C. J. Appl. Physiol. 1979, 47, 712-717. [CrossRef]

68. Bakker, A.; Zweije, R.; van Tienhoven, G.; Kok, H.P.; Sijbrands, J.; van den Bongard, H.J.G.D.; Rasch, C.R.N.; Crezee, H. Two high-resolution thermal monitoring sheets for clinical superficial hyperthermia. Phys. Med. Biol. 2020, 65, 175021. [CrossRef]

69. Paiella, S.; Casetti, L.; Ewald, J.; Marchese, U.; D’Onofrio, M.; Garnier, J.; Landoni, L.; Gilabert, M.; Manzini, G.; Esposito, A.; et al. Laser Treatment (imILT) of Pancreatic Cancer: Safety and Feasibility Results From Two Phase 2a Studies. J. Surg. Res. 2021, 259, 1-7. [CrossRef]

70. Diehn, F.E.; Neeman, Z.; Hvizda, J.L.; Wood, B.J. Remote Thermometry to Avoid Complications in Radiofrequency Ablation. J. Vasc. Interv. Radiol. 2003, 14, 1569-1576. [CrossRef] [PubMed]

71. Kuang, M.; Lu, M.D.; Xie, X.Y.; Xu, H.X.; Mo, L.Q.; Liu, G.J.; Xu, Z.F.; Zheng, Y.L.; Liang, J.Y. Liver cancer: Increased microwave delivery to ablation zone with cooled-shaft antenna-Experimental and clinical studies. Radiology 2007, 242, 914-924. [CrossRef]

72. Baldini, F.; Giannetti, A.; Mencaglia, A.A.; Trono, C. Fiber Optic Sensors for Biomedical Applications. Curr. Anal. Chem. 2008, 4, 378-390. [CrossRef]

73. Tosi, D.; Poeggel, S.; Iordachita, I.; Schena, E. Fiber optic sensors for biomedical applications. In Opto-Mechanical Fiber Optic Sensors; Elsevier: Amsterdam, The Netherlands, 2018; pp. 301-333.

74. Schena, E.; Tosi, D.; Saccomandi, P.; Lewis, E.; Kim, T. Fiber optic sensors for temperature monitoring during thermal treatments: An overview. Sensors 2016, 16, 1144. [CrossRef]

75. Roriz, P.; Silva, S.; Frazão, O.; Novais, S. Optical fiber temperature sensors and their biomedical applications. Sensors 2020, 20, 2113. [CrossRef] [PubMed]

76. Lo Presti, D.; Massaroni, C.; Jorge Leitao, C.S.; De Fatima Domingues, M.; Sypabekova, M.; Barrera, D.; Floris, I.; Massari, L.; Oddo, C.M.; Sales, S.; et al. Fiber bragg gratings for medical applications and future challenges: A review. IEEE Access 2020, 8, 156863-156888. [CrossRef]

77. Massaroni, C.; Zaltieri, M.; Lo Presti, D.; Nicolo, A.; Tosi, D.; Schena, E. Fiber Bragg Grating Sensors for Cardiorespiratory Monitoring: A Review. IEEE Sens. J. 2020, 1. [CrossRef]

78. Lou, J.; Finegan, T.M.; Mohsen, P.; Hatton, T.A.; Laibinis, P.E. Fluorescence-based Thermometry Principles and Applications. Rev. Anal. Chem. 1999, 18, 235-284. [CrossRef]

79. Haines, D.E.; Verow, A.F. Observations on electrode-tissue interface temperature and effect on electrical impedance during radiofrequency ablation of ventricular myocardium. Circulation 1990, 82, 1034-1038. [CrossRef] [PubMed]

80. Blouin, L.T.; Marcus, F.I.; Lampe, L. Assessment of Effects of a Radiofrequency Energy Field and Thermistor Location in an Electrode Catheter on the Accuracy of Temperature Measurement. Pacing Clin. Electrophysiol. 1991, 14, 807-813. [CrossRef]

81. Whayne, J.G.; Nath, S.; Haines, D.E. Microwave catheter ablation of myocardium in vitro. Assessment of the characteristics of tissue heating and injury. Circulation 1994, 89, 2390-2395. [CrossRef]

82. Viallon, M.; Terraz, S.; Roland, J.; Dumont, E.; Becker, C.D.; Salomir, R. Observation and correction of transient cavitation-induced PRFS thermometry artifacts during radiofrequency ablation, using simultaneous Ultrasound/MR imaging. Med. Phys. 2010, 37, 1491-1506. [CrossRef]

83. Chen, J.C.; Moriarty, J.A.; Derbyshire, J.A.; Peters, R.D.; Trachtenberg, J.; Bell, S.D.; Doyle, J.; Arrelano, R.; Wright, G.A.; Henkelman, R.M. Prostate cancer: MR imaging and thermometry during microwave thermal ablation-initial experience. Radiology 2000, 214, 290-297. [CrossRef] [PubMed]

84. Yang, D.; Converse, M.C.; Mahvi, D.M.; Webster, J.G. Measurement and analysis of tissue temperature during microwave liver ablation. IEEE Trans. Biomed. Eng. 2006, 54, 150-155. [CrossRef]

85. van den Bosch, M.; Daniel, B.; Rieke, V.; Butts-Pauly, K.; Kermit, E.; Jeffrey, S. MRI-guided radiofrequency ablation of breast cancer: Preliminary clinical experience. J. Magn. Reson. Imaging Off. J. Int. Soc. Magn. Reson. Med. 2008, 27, 204-208. [CrossRef] [PubMed] 
86. Kawasaki, B.S.; Hill, K.O.; Johnson, D.C.; Fujii, Y. Narrow-band Bragg reflectors in optical fibers. Opt. Lett. 1978, 3, 66-68. [CrossRef] [PubMed]

87. Erdogan, T. Fiber grating spectra. J. Light. Technol. 1997, 15, 1277-1294. [CrossRef]

88. Cavaiola, C.; Saccomandi, P.; Massaroni, C.; Tosi, D.; Giurazza, F.; Frauenfelder, G.; Beomonte Zobel, B.; Di Matteo, F.M.; Caponero, M.A.; Polimadei, A.; et al. Error of a temperature probe for cancer ablation monitoring caused by respiratory movements: Ex vivo and in vivo analysis. IEEE Sens. J. 2016, 16, 5934-5941. [CrossRef]

89. De Tommasi, F.; Massaroni, C.; Carnevale, A.; Lo Presti, D.; De Vita, E.; Iadicicco, A.; Faiella, E.; Grasso, R.F.; Longo, U.G.; Campopiano, S.; et al. Fiber Bragg Grating Sensors for Temperature Monitoring During Thermal Ablation Procedure: Experimental Assessment of Artefact Caused by Respiratory Movements. IEEE Sens. J. 2021, 21, 13342-13349. [CrossRef]

90. Palumbo, G.; Iadicicco, A.; Tosi, D.; Verze, P.; Carlomagno, N.; Tammaro, V.; Ippolito, J.; Campopiano, S. Temperature profile of ex-vivo organs during radio frequency thermal ablation by fiber Bragg gratings. J. Biomed. Opt. 2016, 21, 117003. [CrossRef] [PubMed]

91. Jelbuldina, M.; Korobeinyk, A.V.; Korganbayev, S.; Inglezakis, V.J.; Tosi, D. Fiber Bragg grating based temperature profiling in ferromagnetic nanoparticles-enhanced radiofrequency ablation. Opt. Fiber Technol. 2018, 43, 145-152. [CrossRef]

92. Zaltieri, M.; Allegretti, G.; Massaroni, C.; Schena, E.; Cauti, F.M. Fiber bragg grating sensors for millimetric-scale temperature monitoring of cardiac tissue undergoing radiofrequency ablation: A feasibility assessment. Sensors 2020, 20, 6490. [CrossRef] [PubMed]

93. Lee, D.L.; Wong, Y.H.; Cheah, P.L.; Tan, D.; Lim, K.S.; Ahmad, A.C.; Sulaiman, N.; Abdullah, B.J.J.; Yeong, C.H. Correlation between CT Number shift and tissue temperature change during radiofrequency ablation: An ex-vivo study using bovine liver. J. Phys. Conf. Ser. 2019, 1248, 12039.

94. Polito, D.; Caponero, M.A.; Polimadei, A.; Saccomandi, P.; Massaroni, C.; Silvestri, S.; Schena, E. A needlelike probe for temperature monitoring during laser ablation based on fiber Bragg grating: Manufacturing and characterization. J. Med. Devices Trans. ASME 2015, 9, 041006. [CrossRef]

95. Korganbayev, S.; Orrico, A.; Bianchi, L.; De Landro, M.; Wolf, A.; Dostovalov, A.; Saccomandi, P. Closed-loop temperature control based on fiber bragg grating sensors for laser ablation of hepatic tissue. Sensors 2020, 20, 6496. [CrossRef]

96. De Vita, E.; De Landro, M.; Massaroni, C.; Iadicicco, A.; Saccomandi, P.; Schena, E.; Campopiano, S. Fiber optic sensors-based thermal analysis of perfusion-mediated tissue cooling in liver undergoing laser ablation. IEEE Trans. Biomed. Eng. 2020, 1. [CrossRef]

97. Gassino, R.; Vallan, A.; Perrone, G. Evaluation of temperature measurement errors due to FBG sensors during laser ablation of Ex-Vivo porcine liver. In Proceedings of the I2MTC 2018-2018 IEEE International Instrumentation and Measurement Technology Conference: Discovering New Horizons in Instrumentation and Measurement, Houston, TX, USA, 14-17 May 2018 ; pp. 1-5.

98. Jelbuldina, M.; Korobeinyk, A.; Korganbayev, S.; Tosi, D.; Dukenbayev, K.; Inglezakis, V.J. Real-Time Temperature Monitoring in Liver during Magnetite Nanoparticle-Enhanced Microwave Ablation with Fiber Bragg Grating Sensors: Ex Vivo Analysis. IEEE Sens. J. 2018, 18, 8005-8011. [CrossRef]

99. Saccomandi, P.; Schena, E.; Massaroni, C.; Fong, Y.; Grasso, R.F.; Giurazza, F.; Beomonte Zobel, B.; Buy, X.; Palussiere, J.; Cazzato, R.L. Temperature monitoring during microwave ablation in ex vivo porcine livers. Eur. J. Surg. Oncol. 2015, 41, 1699-1705. [CrossRef]

100. Schena, E.; Villani, S.; Massaroni, C.; Fong, Y.; Saccomandi, P.; Diana, M.; Marescaux, J. Three-Dimensional Temperature Map During Microwave Ablation of Ex Vivo Porcine Liver: Theoretical Prediction and Experimental Validation. In Proceedings of the 2016 Nanotechnology for Instrumentation and Measurement (NANOfIM), Chemnitz, Germany, 8-9 September 2016; pp. 5-16.

101. Zaltieri, M.; De Vita, E.; De Tommasi, F.; Massaroni, C.; Faiella, E.; Zobel, B.B.; Iadicicco, A.; Schena, E.; Grasso, R.F.; Campopiano, S. Evaluation of the Thermal Response of Liver Tissue Undergoing Microwave Treatment by Means of Fiber Bragg Grating Sensors. In Proceedings of the 2020 IEEE Sensors, Taiwan, China, 29-30 August 2020; pp. 1-4.

102. Jelbuldina, M.; Korganbayev, S.; Seidagaliyeva, Z.; Sovetov, S.; Tuganbekov, T.; Tosi, D. Fiber Bragg Grating Sensor for Temperature Monitoring During HIFU Ablation of Ex Vivo Breast Fibroadenoma. IEEE Sens. Lett. 2019, 3, 1-4. [CrossRef]

103. Rao, Y.J.; Webb, D.J.; Jackson, D.A.; Zhang, L.; Bennion, I. In-fiber bragg-grating temperature sensor system for medical applications. J. Light. Technol. 1997, 15, 779-784. [CrossRef]

104. Goldman, L.W. Principles of CT and CT technology. J. Nucl. Med. Technol. 2007, 35, 115-128. [CrossRef] [PubMed]

105. Homolka, P.; Gahleitner, A.; Nowotny, R. Temperature dependence of HU values for various water equivalent phantom materials. Phys. Med. Biol. 2002, 47, 2917. [CrossRef] [PubMed]

106. Zamenhof, R.G.; Sternick, E.S.; Curran, B.M. Non-invasive temperature mapping by computerized tomography. Int. J. Radiat. Oncol. Biol. Phys. 1981, 7, 1235. [CrossRef]

107. Fallone, B.G.; Moran, P.R.; Podgorsak, E.B. Noninvasive thermometry with a clinical x-ray CT scanner. Med. Phys. 1982, 9, 715-721. [CrossRef]

108. Bentzen, S.M.; Overgaard, J.; Jørgensen, J. Isotherm mapping in hyperthermia using subtraction X-ray computed tomography. Radiother. Oncol. 1984, 2, 255-260. [CrossRef] 
109. Schena, E.; Massaroni, C.; Giurazza, F.; Park, J.; Park, J.; Fong, Y.; Saccomandi, P. Feasibility Assessment and Analysis of Thermal Sensitivity of CT-Thermometry During Microwave Ablation of Ex Vivo Porcine Kidneys. In 2016 Nanotechnology for Instrumentation and Measurement (NANOfIM); Institute of Electrical and Electronics Engineers: Piscataway, NJ, USA, 2016; pp. 5-16.

110. Paul, J.; Vogl, T.J.; Chacko, A. Dual energy computed tomography thermometry during hepatic microwave ablation in an ex-vivo porcine model. Phys. Med. 2015, 31, 683-691. [CrossRef]

111. Saccomandi, P.; De Landro, M.; Massaroni, C.; Fong, Y.; Park, J.; Park, J.; Schena, E. Temperature map of kidneys undergoing microwave ablation using computed tomography-thermometry: Ex-vivo experiments and numerical simulations. In Proceedings of the 2019 IEEE International Symposium on Medical Measurements and Applications (MeMeA), Istanbul, Turkey, 26-28 June 2019; pp. 1-6.

112. Pohlan, J.; Kress, W.; Hermann, K.-G.; Mews, J.; Kroes, M.; Hamm, B.; Diekhoff, T. Computed tomography thermography for ablation zone prediction in microwave ablation and cryoablation: Advantages and challenges in an ex vivo porcine liver model. $J$. Comput. Assist. Tomogr. 2020, 44, 744-749. [CrossRef]

113. Tan, D.; Lim, K.-S.; Wong, Y.-H.; Abd Raziff, H.H.; Tan, S.-H.; Sulaiman, N.; Abdullah, B.J.J.; Ahmad, H.; Yeong, C.-H. Multivariate Regression Between Hounsfield Unit Shift, Tissue Temperature, and Tissue Contraction: A Feasibility Study of Computed Tomography Thermometry. IEEE Trans. Instrum. Meas. 2021, 70, 1-9.

114. Tan, D.; Mohamad, N.A.; Wong, Y.H.; Yeong, C.H.; Cheah, P.L.; Sulaiman, N.; Abdullah, B.J.J.; Fabell, M.K.; Lim, K.S. Experimental assessment on feasibility of computed tomography-based thermometry for radiofrequency ablation on tissue equivalent polyacrylamide phantom. Int. J. Hyperth. 2019, 36, 553-560. [CrossRef] [PubMed]

115. Weiss, N.; Goldberg, S.N.; Sosna, J.; Azhari, H. Temperature-density hysteresis in X-ray CT during HIFU thermal ablation: Heating and cooling phantom study. Int. J. Hyperth. 2014, 30, 27-35. [CrossRef] [PubMed]

116. Weiss, N.; Sosna, J.; Goldberg, S.N.; Azhari, H. Non-invasive temperature monitoring and hyperthermic injury onset detection using X-ray CT during HIFU thermal treatment in ex vivo fatty tissue. Int. J. Hyperth. 2014, 30, 119-125. [CrossRef] [PubMed]

117. Fani, F.; Schena, E.; Saccomandi, P.; Silvestri, S. CT-based thermometry: An overview. Int. J. Hyperth. 2014, 30, 219-227. [CrossRef]

118. Wells, P.N.T. Ultrasound imaging. Phys. Med. Biol. 2006, 51, R83. [CrossRef]

119. Rivens, I.; Shaw, A.; Civale, J.; Morris, H. Treatment monitoring and thermometry for therapeutic focused ultrasound. Int. J. Hyperth. 2007, 23, 121-139. [CrossRef]

120. Nasoni, R.L.; Bowen, T.; Connor, W.G.; Sholes, R.R. In vivo temperature dependence of ultrasound speed in tissue and its application to noninvasive temperature monitoring. Ultrason. Imaging 1979, 1, 34-43. [CrossRef]

121. Giurazza, F.; Massaroni, C.; Silvestri, S.; Zobel, B.B.; Schena, E. Preliminary analysis of ultrasound elastography imaging-based thermometry on non-perfused ex vivo swine liver. J. Ultrasound 2020, 23, 69-75. [CrossRef]

122. Varghese, T.; Zagzebski, J.A.; Chen, Q.; Techavipoo, U.; Frank, G.; Johnson, C.; Wright, A.; Lee, F.T., Jr. Ultrasound monitoring of temperature change during radiofrequency ablation: Preliminary in-vivo results. Ultrasound Med. Biol. 2002, 28, 321-329. [CrossRef]

123. Liu, Y.-D.; Li, Q.; Zhou, Z.; Yeah, Y.-W.; Chang, C.-C.; Lee, C.-Y.; Tsui, P.-H. Adaptive ultrasound temperature imaging for monitoring radiofrequency ablation. PLoS ONE 2017, 12, e0182457. [CrossRef] [PubMed]

124. Yang, C.; Wu, S.; Bai, Y.; Gao, H. Ultrasound monitoring of temperature and coagulation change during tumor treatment with microwave ablation. Front. Biol. China 2009, 4, 254-259. [CrossRef]

125. Lewis, M.A.; Staruch, R.M.; Chopra, R. Thermometry and ablation monitoring with ultrasound. Int. J. Hyperth. 2015, 31, 163-181. [CrossRef]

126. Vlaardingerbroek, M.T.; Boer, J.A. Magnetic Resonance Imaging: Theory and Practice; Springer: Berlin, Germany, 2003; ISBN 978-3-540-43681-2.

127. Quesson, B.; de Zwart, J.A.; Moonen, C.T.W. Magnetic resonance temperature imaging for guidance of thermotherapy. J. Magn. Reson. Imaging Off. J. Int. Soc. Magn. Reson. Med. 2000, 12, 525-533. [CrossRef]

128. Bertsch, F.; Mattner, J.; Stehling, M.K.; Müller-Lisse, U.; Peller, M.; Loeffler, R.; Weber, J.; Meßmer, K.; Wilmanns, W.; Issels, R.; et al. Non-invasive temperature mapping using MRI: Comparison of two methods based on chemical shift and T1-relaxation. Magn. Reson. Imaging 1998, 16, 393-403. [CrossRef]

129. Denis de Senneville, B.; Quesson, B.; Moonen, C.T.W. Magnetic resonance temperature imaging. Int. J. Hyperth. 2005, $21,515-531$. [CrossRef]

130. Winter, L.; Oberacker, E.; Paul, K.; Ji, Y.; Oezerdem, C.; Ghadjar, P.; Thieme, A.; Budach, V.; Wust, P.; Niendorf, T. Magnetic resonance thermometry: Methodology, pitfalls and practical solutions. Int. J. Hyperth. 2016, 32, 63-75. [CrossRef] [PubMed]

131. Jolesz, F.A.; Bleier, A.R.; Jakab, P.; Ruenzel, P.W.; Huttl, K.; Jako, G.J. MR imaging of laser-tissue interactions. Radiology 1988, 168, 249-253. [CrossRef]

132. Rieke, V.; Kinsey, A.M.; Ross, A.B.; Nau, W.H.; Diederich, C.J.; Sommer, G.; Pauly, K.B. Referenceless MR thermometry for monitoring thermal ablation in the prostate. IEEE Trans. Med. Imaging 2007, 26, 813-821. [CrossRef]

133. Breen, M.S.; Breen, M.; Butts, K.; Chen, L.; Saidel, G.M.; Wilson, D.L. MRI-guided thermal ablation therapy: Model and parameter estimates to predict cell death from MR thermometry images. Ann. Biomed. Eng. 2007, 35, 1391-1403. [CrossRef] [PubMed] 
134. Saccomandi, P.; Massaroni, C.; Silvestri, S.; Giurazza, F.; Frauenfelder, G.; Zobel, B.B.; Schena, E. Feasibility assessment of magnetic resonance-thermometry on pancreas undergoing laser ablation: Sensitivity analysis of three sequences. Measurement 2016, 80, 21-28. [CrossRef]

135. Rosenberg, C.; Kickhefel, A.; Mensel, B.; Pickartz, T.; Puls, R.; Roland, J.; Hosten, N. PRFS-based MR thermometry versus an alternative T1 magnitude method-comparative performance predicting thermally induced necrosis in hepatic tumor ablation. PLoS ONE 2013, 8, e78559. [CrossRef]

136. Puls, R.; Langner, S.; Rosenberg, C.; Hegenscheid, K.; Kuehn, J.P.; Noeckler, K.; Hosten, N. Laser ablation of liver metastases from colorectal cancer with MR thermometry: 5-year survival. J. Vasc. Interv. Radiol. 2009, 20, 225-234. [CrossRef]

137. Woodrum, D.A.; Mynderse, L.A.; Gorny, K.R.; Amrami, K.K.; McNichols, R.J.; Callstrom, M.R. 3.0 T MR-guided laser ablation of a prostate cancer recurrence in the postsurgical prostate bed. J. Vasc. Interv. Radiol. 2011, 22, 929-934. [CrossRef]

138. Seror, O.; Lepetit-Coiffé, M.; Le Bail, B.; De Senneville, B.D.; Trillaud, H.; Moonen, C.; Quesson, B. Real time monitoring of radiofrequency ablation based on MR thermometry and thermal dose in the pig liver in vivo. Eur. Radiol. 2008, 18, 408-416. [CrossRef] [PubMed]

139. Holbrook, A.B.; Santos, J.M.; Kaye, E.; Rieke, V.; Pauly, K.B. Real-time MR thermometry for monitoring HIFU ablations of the liver. Magn. Reson. Med. Off. J. Int. Soc. Magn. Reson. Med. 2010, 63, 365-373. [CrossRef]

140. Ni, Y.; Mulier, S.; Miao, Y.; Michel, L.; Marchal, G. A review of the general aspects of radiofrequency ablation. Abdom. Imaging 2005, 30, 381-400. [CrossRef] [PubMed]

141. Rosenthal, D.I.; Alexander, A.; Rosenberg, A.E.; Springfield, D. Ablation of Osteoid Osteomas with a Percutaneously Placed Electrode: A New Procedure. Musculoskelet. Radiol. 1992, 183, 29-33. [CrossRef]

142. Kojima, H.; Tanigawa, N.; Kariya, S.; Komemushi, A.; Shomura, Y.; Sawada, S. Clinical assessment of percutaneous radiofrequency ablation for painful metastatic bone tumors. Cardiovasc. Intervent. Radiol. 2006, 29, 1022-1026. [CrossRef]

143. Hoffmann, R.T.; Jakobs, T.F.; Trumm, C.; Weber, C.; Helmberger, T.K.; Reiser, M.F. Radiofrequency ablation in combination with osteoplasty in the treatment of painful metastatic bone disease. J. Vasc. Interv. Radiol. 2008, 19, 419-425. [CrossRef] [PubMed]

144. Toyota, N.; Naito, A.; Kakizawa, H.; Hieda, M.; Hirai, N.; Tachikake, T.; Kimura, T.; Fukuda, H.; Ito, K. Radiofrequency ablation therapy combined with cementoplasty for painful bone metastases: Initial experience. Cardiovasc. Intervent. Radiol. 2005, 28, 578-583. [CrossRef] [PubMed]

145. Lane, M.D.; Le, H.B.Q.; Lee, S.; Young, C.; Heran, M.K.S.; Badii, M.; Clarkson, P.W.; Munk, P.L. Combination radiofrequency ablation and cementoplasty for palliative treatment of painful neoplastic bone metastasis: Experience with 53 treated lesions in 36 patients. Skelet. Radiol. 2011, 40, 25-32. [CrossRef]

146. Simon, M.A.; Rosenthal, D.I.; Hornicek, F.J.; Wolfe, M.W.; Jennings, L.C.; Gebhardt, M.C.; Mankin, H.J. Percutaneous radiofrequency coagulation of osteoid osteoma compared with operative treatment. J. Bone Jt. Surg. Ser. A 1999, 81, 437-438.

147. Callstrom, M.R.; Charboneau, J.W.; Goetz, M.P.; Rubin, J.; Wong, G.Y.; Sloan, J.A.; Novotny, P.J.; Lewis, B.D.; Welch, T.J.; Farrell, M.A. Painful metastases involving bone: Feasibility of percutaneous CT-and US-guided radio-frequency ablation. Radiology 2002, 224, 87-97. [CrossRef]

148. Rachbauer, F.; Mangat, J.; Bodner, G.; Eichberger, P.; Krismer, M. Heat distribution and heat transport in bone during radiofrequency catheter ablation. Arch. Orthop. Trauma Surg. 2003, 123, 86-90. [CrossRef]

149. Bitsch, R.G.; Rupp, R.; Bernd, L.; Ludwig, K. Osteoid osteoma in an ex vivo animal model: Temperature changes in surrounding soft tissue during CT-guided radiofrequency ablation. Radiology 2006, 238, 107-112. [CrossRef] [PubMed]

150. Adachi, A.; Kaminou, T.; Ogawa, T.; Kawai, T.; Takaki, Y.; Sugiura, K.; Ohuchi, Y.; Hashimoto, M. Heat distribution in the spinal canal during radiofrequency ablation for vertebral lesions: Study in swine. Radiology 2008, 247, 374-380. [CrossRef] [PubMed]

151. Nakatsuka, A.; Yamakado, K.; Takaki, H.; Uraki, J.; Makita, M.; Oshima, F.; Takeda, K. Percutaneous radiofrequency ablation of painful spinal tumors adjacent to the spinal cord with real-time monitoring of spinal canal temperature: A prospective study. Cardiovasc. Intervent. Radiol. 2009, 32, 70-75. [CrossRef]

152. Groetz, S.F.; Birnbaum, K.; Meyer, C.; Strunk, H.; Schild, H.H.; Wilhelm, K.E. Thermometry during coblation and radiofrequency ablation of vertebral metastases: A cadaver study. Eur. Spine J. 2013, 22, 1389-1393. [CrossRef]

153. Pezeshki, P.S.; Woo, J.; Akens, M.K.; Davies, J.E.; Gofeld, M.; Whyne, C.M.; Yee, A.J.M. Evaluation of a bipolar-cooled radiofrequency device for ablation of bone metastases: Preclinical assessment in porcine vertebrae. Spine J. 2014, 14, 361-370. [CrossRef]

154. Greenberg, A.; Berenstein Weyel, T.; Sosna, J.; Applbaum, J.; Peyser, A. The distribution of heat in bone during radiofrequency ablation of an ex vivo bovine model of osteoid osteoma. Bone Jt. J. 2014, 96, 677-683. [CrossRef]

155. Bornemann, R.; Pflugmacher, R.; Frey, S.P.; Roessler, P.P.; Rommelspacher, Y.; Wilhelm, K.E.; Sander, K.; Wirtz, D.C.; Grötz, S.F. Temperature distribution during radiofrequency ablation of spinal metastases in a human cadaver model: Comparison of three electrodes. Technol. Health Care 2016, 24, 647-653. [CrossRef]

156. Zhao, W.; Peng, Z.H.; Chen, J.Z.; Hu, J.H.; Huang, J.Q.; Jiang, Y.N.; Luo, G.; Yi, G.F.; Wang, H.; Jin, S.; et al. Thermal effect of percutaneous radiofrequency ablation with a clustered electrode for vertebral tumors: In vitro and vivo experiments and clinical application. J. Bone Oncol. 2018, 12, 69-77. [CrossRef]

157. Mayer, T.; Cazzato, R.L.; De Marini, P.; Auloge, P.; Dalili, D.; Koch, G.; Garnon, J.; Gangi, A. Spinal metastases treated with bipolar radiofrequency ablation with increased $(>70 \mathrm{C})$ target temperature: Pain management and local tumor control. Diagn. Interv. Imaging 2021, 102, 27-34. [CrossRef] 
158. Lecigne, R.; Cazzato, R.L.; Dalili, D.; Gangi, A.; Garnon, J. Transosseous Temperature Monitoring of the Anterior Epidural Space during Thermal Ablation in the Thoracic Spine. Cardiovasc. Intervent. Radiol. 2021, 44, 982-987. [CrossRef] [PubMed]

159. Schena, E.; Saccomandi, P.; Fong, Y. Laser ablation for cancer: Past, present and future. J. Funct. Biomater. 2017, 8, 19. [CrossRef] [PubMed]

160. Muller, G.; Roggan, A. Laser-Induced Interstitial Thermotherapy; SPIE Press: Bellingham, WA, USA, 1995.

161. Gangi, A.; Dietemann, J.-L.; Guth, S.; Vinclair, L.; Sibilia, J.; Mortazavi, R.; Steib, J.P.; Roy, C. Percutaneous laser photocoagulation of spinal osteoid osteomas under CT guidance. Am. J. Neuroradiol. 1998, 19, 1955-1958.

162. Ghia, A.J.; Rebueno, N.C.; Li, J.; Brown, P.D.; Rhines, L.D.; Tatsui, C.E. The use of image guided laser interstitial thermotherapy to supplement spine stereotactic radiosurgery to manage metastatic epidural spinal cord compression: Proof of concept and dosimetric analysis. In Practical Radiation Oncology; Spriger Link: Berlin, Germany, 2016; Volume 6, pp. e35-e38.

163. Moser, T.; Giacomelli, M.-C.; Clavert, J.-M.; Buy, X.; Dietemann, J.-L.; Gangi, A. Image-guided laser ablation of osteoid osteoma in pediatric patients. J. Pediatr. Orthop. 2008, 28, 265-270. [CrossRef] [PubMed]

164. Maurer, M.H.; Gebauer, B.; Wieners, G.; De Bucourt, M.; Renz, D.M.; Hamm, B.; Streitparth, F. Treatment of osteoid osteoma using CT-guided radiofrequency ablation versus MR-guided laser ablation: A cost comparison. Eur. J. Radiol. 2012, 81, e1002-e1006. [CrossRef]

165. Binkert, C.A.; Nanz, D.; Bootz, F.; Nehrbass, D.; Pospischil, A.; Boos, N.; Pfammatter, T.; Treiber, K.; Hodler, J. Laser-Induced Thermotherapy of the Vertebral Body. Investig. Radiol. 2002, 37, 557-561. [CrossRef]

166. Sequeiros, R.B.; Hyvönen, P.; Sequeiros, A.B.; Jyrkinen, L.; Ojala, R.; Klemola, R.; Vaara, T.; Tervonen, O. MR imaging-guided laser ablation of osteoid osteomas with use of optical instrument guidance at 0.23 T. Eur. Radiol. 2003, 13, 2309-2314. [CrossRef]

167. Streitparth, F.; Gebauer, B.; Melcher, I.; Schaser, K.; Philipp, C.; Rump, J.; Hamm, B.; Teichgräber, U. MR-guided laser ablation of osteoid osteoma in an open high-field system (1.0 T). Cardiovasc. Intervent. Radiol. 2009, 32, 320-325. [CrossRef]

168. Streitparth, F.; Teichgräber, U.; Walter, T.; Schaser, K.D.; Gebauer, B. Recurrent osteoid osteoma: Interstitial laser ablation under magnetic resonance imaging guidance. Skelet. Radiol. 2010, 39, 1131-1137. [CrossRef]

169. Tatsui, C.E.; Stafford, R.J.; Li, J.; Sellin, J.N.; Amini, B.; Rao, G.; Suki, D.; Ghia, A.J.; Brown, P.; Lee, S.H.; et al. Utilization of laser interstitial thermotherapy guided by real-time thermal MRI as an alternative to separation surgery in the management of spinal metastasis. J. Neurosurg. Spine 2015, 23, 400-411. [CrossRef]

170. Tatsui, C.E.; Lee, S.-H.; Amini, B.; Rao, G.; Suki, D.; Oro, M.; Brown, P.D.; Ghia, A.J.; Bhavsar, S.; Popat, K. Spinal laser interstitial thermal therapy: A novel alternative to surgery for metastatic epidural spinal cord compression. Neurosurgery 2016, 79, S73-S82. [CrossRef] [PubMed]

171. Simon, C.J.; Dupuy, D.E.; Mayo-Smith, W.W. Microwave ablation: Principles and applications. Radiographics 2005, 25, S69-S83. [CrossRef]

172. Fan, Q.; Ma, B.; Qiu, X.; Li, Y.; Ye, J.; Zhou, Y. Preliminary report on treatment of bone tumors with microwave-induced hyperthermia. Bioelectromagn. J. Bioelectromagn. Soc. Soc. Phys. Regul. Biol. Med. Eur. Bioelectromagn. Assoc. 1996, 17, 218-222. [CrossRef]

173. Fan, Q.; Ma, B.; Guo, A.; Li, Y.; Ye, J.; Zhou, Y.; Qiu, X. Surgical treatment of bone tumors in conjunction with microwave-induced hyperthermia and adjuvant immunotherapy. A preliminary report. Chin. Med. J. 1996, 109, 425-431. [PubMed]

174. Prud'homme, C.; Nueffer, J.-P.; Runge, M.; Dubut, J.; Kastler, B.; Aubry, S. Prospective pilot study of CT-guided microwave ablation in the treatment of osteoid osteomas. Skelet. Radiol. 2017, 46, 315-323. [CrossRef]

175. Pusceddu, C.; Sotgia, B.; Fele, R.M.; Ballicu, N.; Melis, L. Combined microwave ablation and cementoplasty in patients with painful bone metastases at high risk of fracture. Cardiovasc. Intervent. Radiol. 2016, 39, 74-80. [CrossRef] [PubMed]

176. Kostrzewa, M.; Diezler, P.; Michaely, H.; Rathmann, N.; Attenberger, U.I.; Schoenberg, S.O.; Diehl, S.J. Microwave ablation of osteoid osteomas using dynamic MR imaging for early treatment assessment: Preliminary experience. J. Vasc. Interv. Radiol. 2014, 25, 106-111. [CrossRef]

177. Rinzler, E.S.; Shivaram, G.M.; Shaw, D.W.; Monroe, E.J.; Koo, K.S.H. Microwave ablation of osteoid osteoma: Initial experience and efficacy. Pediatr. Radiol. 2019, 49, 566-570. [CrossRef]

178. Kastler, A.; Alnassan, H.; Aubry, S.; Kastler, B. Microwave thermal ablation of spinal metastatic bone tumors. J. Vasc. Interv. Radiol. 2014, 25, 1470-1475. [CrossRef] [PubMed]

179. Fan, Q.Y.; Zhou, Y.; Zhang, M.; Ma, B.; Yang, T.; Long, H.; Yu, Z.; Li, Z. Microwave ablation of malignant extremity bone tumors. Springerplus 2016, 5, 1373. [CrossRef] [PubMed]

180. Kastler, A.; Krainik, A.; Sakhri, L.; Mousseau, M.; Kastler, B. Feasibility of Real-Time Intraprocedural Temperature Control during Bone Metastasis Thermal Microwave Ablation: A Bicentric Retrospective Study. J. Vasc. Interv. Radiol. 2017, 28, 366-371. [CrossRef]

181. De Vita, E.; Zaltieri, M.; De Tommasi, F.; Massaroni, C.; Faiella, E.; Zobel, B.B.; Iadicicco, A.; Schena, E.; Grasso, R.F.; Campopiano, S. Multipoint temperature monitoring of microwave thermal ablation in bones through fiber bragg grating sensor arrayst. Sensors 2020, 20, 3200. [CrossRef]

182. De Tommasi, F.; Zaltieri, M.; Schena, E.; Massaroni, C.; Faiella, E.; Grasso, R.F.; Zobel, B.B.; De Vita, E.; Iadicicco, A.; Campopiano, S. Temperature Monitoring during Microwave Thermal Ablation of Ex Vivo Bovine Bone: A Pilot Test. In Proceedings of the MetroInd 4.0 \& IoT 2020: 2020 IEEE International Workshop on Metrology for Industry 4.0 and IoT, Rome, Italy, 3 June 2020; pp. 255-259. [CrossRef] 
183. Ke, J.; Cheng, S.; Yang, T.; Zhang, C.; Wang, M.; Zhang, Y. Feasibility of Controlling Metastatic Osseous Pain Using Three Kinds of Image-Guided Procedures for Thermal Microwave Ablation: A Retrospective Study. Orthop. Surg. 2021, 13, 116-125. [CrossRef] [PubMed]

184. ter Haar, G. HIFU tissue ablation: Concept and devices. Adv. Exp. Med. Biol. 2016, 880, 3-20. [CrossRef]

185. Wu, F.; Chen, W.Z.; Bai, J.; Zou, J.Z.; Wang, Z.L.; Zhu, H.; Wang, Z.B. Pathological changes in human malignant carcinoma treated with high-intensity focused ultrasound. Ultrasound Med. Biol. 2001, 27, 1099-1106. [CrossRef]

186. Hurwitz, M.D.; Ghanouni, P.; Kanaev, S.V.; Iozeffi, D.; Gianfelice, D.; Fennessy, F.M.; Kuten, A.; Meyer, J.E.; LeBlang, S.D.; Roberts, A. Magnetic resonance-guided focused ultrasound for patients with painful bone metastases: Phase III trial results. JNCI J. Natl. Cancer Inst. 2014, 106. [CrossRef]

187. Lin, X.; Chen, W.; Wei, F. Technique Success, Technique Efficacy and Complications of HIFU Ablation for Palliation of Pain in Patients With Bone Lesions: A Meta-Analysis of 28 Feasibility Studies. Ultrasound Med. Biol. 2021, 47, 1182-1191. [CrossRef]

188. Catane, R.; Beck, A.; Inbar, Y.; Rabin, T.; Shabshin, N.; Hengst, S.; Pfeffer, R.M.; Hanannel, A.; Dogadkin, O.; Liberman, B. MR-guided focused ultrasound surgery (MRgFUS) for the palliation of pain in patients with bone metastases-Preliminary clinical experience. Ann. Oncol. 2007, 18, 163-167. [CrossRef]

189. Liberman, B.; Gianfelice, D.; Inbar, Y.; Beck, A.; Rabin, T.; Shabshin, N.; Chander, G.; Hengst, S.; Pfeffer, R.; Chechick, A.; et al. Pain palliation in patients with bone metastases using MR-guided focused ultrasound surgery: A multicenter study. Ann. Surg. Oncol. 2009, 16, 140-146. [CrossRef]

190. Bucknor, M.D.; Rieke, V.; Do, L.; Majumdar, S.; Link, T.M.; Saeed, M. MRI-guided high-intensity focused ultrasound ablation of bone: Evaluation of acute findings with MR and CT imaging in a swine model. J. Magn. Reson. Imaging 2014, 40, 1174-1180. [CrossRef] [PubMed]

191. Geiger, D.; Napoli, A.; Conchiglia, A.; Gregori, L.; Arrigoni, F.; Bazzocchi, A.; Busacca, M.; Moreschini, O.; Mastantuono, M.; Albisinni, U.; et al. MR-guided Focused Ultrasound ( MRgFUS ) Ablation for the Treatment of Nonspinal Osteoid Osteoma: A prospective multicenter evaluation. J. Bone Jt. Surg. 2014, 96, 743-751. [CrossRef]

192. Ramsay, E.; Mougenot, C.; Kazem, M.; Laetsch, T.W.; Chopra, R. Temperature-dependent MR signals in cortical bone: Potential for monitoring temperature changes during high-intensity focused ultrasound treatment in bone. Magn. Reson. Med. 2015, 74, 1095-1102. [CrossRef]

193. Lam, M.K.; Huisman, M.; Nijenhuis, R.J.; van den Bosch, M.A.A.J.; Viergever, M.A.; Moonen, C.T.W.; Bartels, L.W. Quality of MR thermometry during palliative MR-guided high-intensity focused ultrasound (MR-HIFU) treatment of bone metastases. J. Ther. Ultrasound 2015, 3, 1-15. [CrossRef] [PubMed]

194. Ozhinsky, E.; Han, M.; Bucknor, M.; Krug, R.; Rieke, V. T2-based temperature monitoring in bone marrow for MR-guided focused ultrasound. J. Ther. Ultrasound 2016, 4, 1-9. [CrossRef] [PubMed]

195. Sharma, K.V.; Yarmolenko, P.S.; Celik, H.; Eranki, A.; Partanen, A.; Smitthimedhin, A.; Kim, A.; Oetgen, M.; Santos, D.; Patel, J. Comparison of noninvasive high-intensity focused ultrasound with radiofrequency ablation of osteoid osteoma. J. Pediatr. 2017, 190, 222-228. [CrossRef]

196. Guillemin, P.C.; Gui, L.; Lorton, O.; Zilli, T.; Crowe, L.A.; Desgranges, S.; Montet, X.; Terraz, S.; Miralbell, R.; Salomir, R.; et al. Mild hyperthermia by MR-guided focused ultrasound in an ex vivo model of osteolytic bone tumour: Optimization of the spatio-temporal control of the delivered temperature. J. Transl. Med. 2019, 17, 1-19. [CrossRef] [PubMed]

197. Lena, B.; Bartels, L.W.; Ferrer, C.J.; Moonen, C.T.W.; Viergever, M.A.; Bos, C. Interleaved water and fat MR thermometry for monitoring high intensity focused ultrasound ablation of bone lesions. Magn. Reson. Med. 2021, 1-9. [CrossRef]

198. Chu, K.F.; Dupuy, D.E. Thermal ablation of tumours: Biological mechanisms and advances in therapy. Nat. Rev. Cancer 2014, 14, 199-208. [CrossRef] [PubMed]

199. Abdo, J.; Cornell, D.L.; Mittal, S.K.; Agrawal, D.K. Immunotherapy plus cryotherapy: Potential augmented abscopal effect for advanced cancers. Front. Oncol. 2018, 8, 85. [CrossRef] [PubMed]

200. Iwai, T.; Oebisu, N.; Hoshi, M.; Orita, K.; Yamamoto, A.; Hamamoto, S.; Kageyama, K.; Nakamura, H. Promising abscopal effect of combination therapy with thermal tumour ablation and intratumoural OK-432 injection in the rat osteosarcoma model. Sci. Rep. 2020, 10, 1-13. [CrossRef] [PubMed]

201. Fionda, B.; Massaccesi, M.; Tagliaferri, L.; Dinapoli, N.; Iezzi, R.; Boldrini, L. Abscopal effect and interventional oncology: State of art and future perspectives. Eur. Rev. Med. Pharmacol. Sci. 2020, 24, 773-776. [PubMed] 